
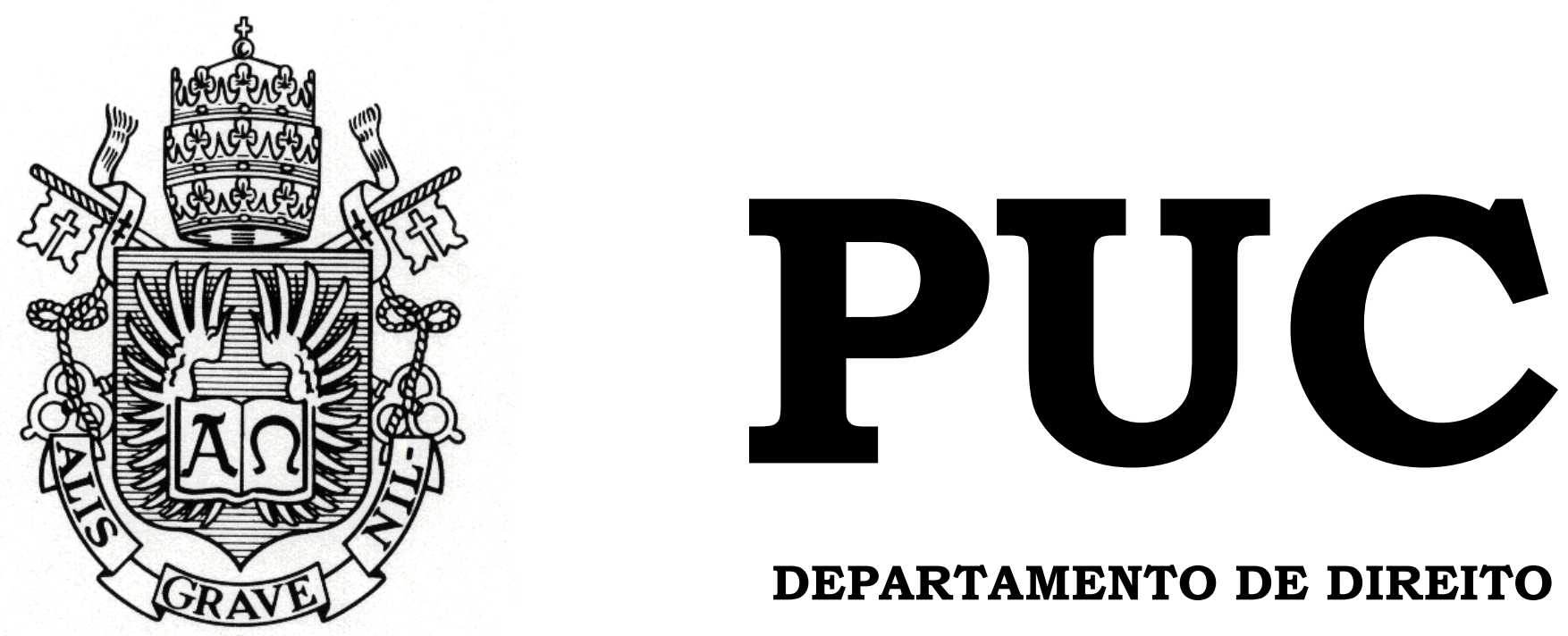

DEPARTAMENTO DE DIREITO

\title{
NOVAS FEIÇÕES DO PODER REGULAMENTAR
}

por

CAIO MAYERHOFFER MACHADO MORAES PESSANHA

ORIENTADOR: AUGUSTO HENRIQUE WERNECK MARTINS

2013.2

PONTIFÍCIA UNIVERSIDADE CATÓLICA DO RIO DE JANEIRO RUA MARQUÊS DE SÃO VICENTE, 225 - CEP 22453-900 RIO DE JANEIRO - BRASIL 


\section{NOVAS FEIÇÕES DO PODER REGULAMENTAR}

por

\section{CAIO MAYERHOFFER MACHADO MORAES PESSANHA}

Monografia apresentada ao Departamento de Direito da Pontifícia Universidade Católica do Rio de Janeiro (PUC-Rio) para a obtenção do Título de Bacharel em Direito.

Orientador: Augusto Henrique Werneck Martins 
À Vovó Zezé, em nome de todos os que me deram especial suporte nesta caminhada. 


\section{RESUMO}

O presente trabalho aborda de uma perspectiva eminentemente crítica a construção clássica do poder regulamentar, como espécie de prerrogativa normativa atribuída ao Chefe do Poder Executivo.

Inicia-se a elaboração, portanto, investigando as novas tendências do Direito Administrativo nacional. São conferidos os diversos elementos e concepções que a doutrina tem destacado como manifestações da constitucionalização da matéria, ressaltando, em especial, aquelas que dialogam com a remodelação do princípio da legalidade.

Assim é que, como estrutura teórica que sempre envolveu o âmbito de acomodação do poder regulamentar, constata-se como o princípio da legalidade tem obtido novas feições. O novo tratamento da legalidade, agora princípio da juridicidade, impacta de formas variadas na relação entre poderes da República, especialmente entre Executivo e Legislativo. De modo que também se analisa a compreensão atual sobre a separação de poderes.

Passados os estudos pertinentes aos fundamentos teóricos do poder regulamentar, são apuradas as novas abordagens concernentes ao regulamento de execução, instituto clássico e comumente confundido como a única faceta da competência regulamentar. Por fim, introduz-se o regulamento autônomo, figura polêmica nos modernos estudos do Direito Administrativo, demonstrando o seu preciso arranjo no ordenamento jurídico brasileiro.

Palavras-chave: Poder regulamentar - Poderes administrativos - Princípio da legalidade - Princípio da juridicidade - Separação de poderes - Atos normativos - Regulamento de execução - Regulamento autônomo 


\section{SUMÁRIO}

INTRODUÇÃO: O PODER REGULAMENTAR..................................... 6

CAPÍTULO 1 - NOVOS PARADIGMAS DO DIREITO

ADMINISTRATIVO....................................................................................... 11

1.1. A concepção de paradigma ............................................................... 11

1.2. A evolução do Direito Administrativo brasileiro ................................ 12

CAPÍTULO 2 - A REVIGORAÇÃO DOS FUNDAMENTOS

TEÓRICOS DE UM PODER REGULAMENTAR_.................................. 22

2.1. Lei, legalidade e juridicidade ............................................................ 22

2.2. A nova separação de poderes................................................................. 29

CAPÍTULO 3 - NOVAS ABORDAGENS A RESPEITO DO

REGULAMENTO DE EXECUÇÃO .............................................................. 36

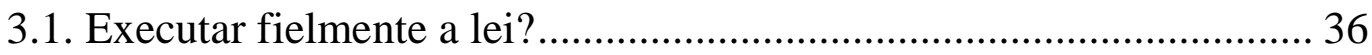

3.2. Controle dos atos regulamentares. A defesa do controle jurisdicional abstrato de constitucionalidade dos regulamentos de execução ................. 43

CAPÍTULO 4 - BREVES APONTAMENTOS SOBRE O

REGULAMENTO AUTÔNOMO NO DIREITO BRASILEIRO............ 50

4.1. Definição, limites e possibilidades ....................................................... 50

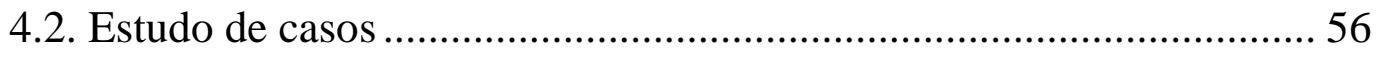

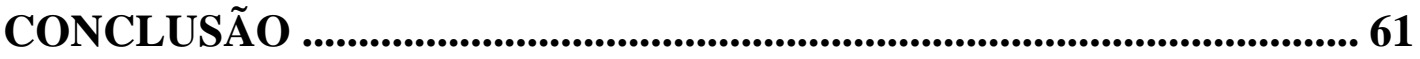

REFERÊNCIAS BIBLIOGRÁFICAS ...................................................64 


\title{
PRINCIPAIS ABREVIAÇÕES
}

\author{
ADI - Ação Direta de Inconstitucionalidade \\ Art. - Artigo \\ CF - Constituição Federal \\ EC - Emenda Constitucional \\ PLS - Projeto de Lei do Senado \\ STF - Supremo Tribunal Federal
}




\section{INTRODUÇÃO: O PODER REGULAMENTAR}

É de Jean Rivero a conceituação de poder regulamentar como "o poder de estatuir por via geral, concedido a autoridades diferentes do Parlamento,

quer nacionais, quer locais" " (grifos nossos). A afirmação do renomado autor francês, de caráter bastante singelo, traz em si uma profundidade não tão notada à primeira vista. Cabe tratar, assim sendo, dos conceitos elementares do que se convencionou chamar por poder regulamentar.

Em primeiro lugar, trata-se de competência destacada no núcleo da capacidade normativa da Administração Pública. A função ou capacidade normativa, por sua vez, insere-se no quadro do que se ajustou nomear "poderes da Administração". Tais poderes, como aponta Floriano de Azevedo Marques Neto, são tratados pela doutrina administrativa majoritária como verdadeiras prerrogativas asseguradas à Administração para que cumpra seus objetivos constitucionais ${ }^{2}$.

Assim é que José dos Santos Carvalho Filho define poderes administrativos como "o conjunto de prerrogativas de direito público que a ordem jurídica confere aos agentes administrativos para o fim de permitir que o Estado alcance seus fins ${ }^{3}$ ". Vê-se, à frente, que o poder administrativo ora em destaque e genericamente tratado é o normativo (capacidade normativa ${ }^{4}$ ), que é simplesmente o de editar normas, nem sempre com pretensão generalizante como ocorre no caso dos regulamentos, e ainda que sem caráter legislativo 5 .

\footnotetext{
${ }^{1}$ RIVERO, Jean. Direito administrativo. Trad. Rogério Ehrhardt. Coimbra: Almedina, 1981, p. 77.

${ }^{2}$ MARQUES NETO, Floriano de Azevedo. Poderes da Administração Pública. In: FIGUEIREDO, Marcelo (Coord.). Novos rumos para o direito público: reflexões em homenagem à Professora Lúcia Valle Figueiredo. Belo Horizonte: Fórum, 2012, p. 224.

${ }^{3}$ CARVALHO FILHO, José dos Santos. Manual de Direito Administrativo. $16^{\mathrm{a}}$ ed. Rio de Janeiro: Lumen Juris, 2006, p. 39.

${ }^{4}$ cf. MARQUES NETO, Floriano de Azevedo. Poderes da Administração Pública, p 226.

${ }^{5}$ Função legislativa aqui entendida a partir do seu caráter formal. Sobre a diferenciação entre função legislativa e normativa, veja-se GRAU, Eros Roberto. O Direito Posto e o Direito Pressuposto. $7^{\mathrm{a}}$ ed. São Paulo: Malheiros, 2008, p. 241.
} 
Daí se conclui que o poder normativo não se esgota no regulamento, já que há casos de alocação legal de competências normativas específicas em órgãos diversos da Administração, ainda que não para propriamente regulamentar a lei atributiva da competência.

Note-se que não se quer dizer com isso que apenas o Chefe do Executivo possa editar regulamentos ${ }^{6}$. Embora, com efeito, esse seja o ensinamento tradicional, respeitada doutrina entende hoje que as agências reguladoras, no exercício de suas competências legalmente definidas e constitucionalmente previstas, também podem regulamentar leis por meio de atos normativos. Têm competência, portanto, para emitir regulamentos de execução ${ }^{7}$.

De qualquer forma, tal debate mereceria um estudo à parte, de modo que a perspectiva aqui tratada a respeito do regulamento de execução examinará a sua hipótese habitual. São, assim, atos normativos secundários, expedidos pelo Chefe do Poder Executivo com fundamento no artigo 84, inciso IV, da Constituição da República, os quais servem para dar maior densidade normativa às leis nos quais estão amparados (sendo estas o ato normativo primário), bem como para completar-lhes o sentido ${ }^{8}$.

O tema do regulamento de execução nem sempre é satisfatoriamente tratado na doutrina publicista nacional. A abrangência e crescente impacto dos decretos regulamentares no ordenamento jurídico e, principalmente, no cotidiano da sociedade, bem como o verdadeiro grau de inovação por eles gerado demandam nova abordagem sobre o instituto. Não é coincidência que Eduardo García de Enterría e Tomáz-Ramón Fernández tenham se referido ao

\footnotetext{
${ }^{6}$ Não é despiciendo relembrar a distinção entre decreto e regulamento: “É pois necessário não cairmos na confusão, frequentemente feita, entre a forma do acto e a sua natureza: decreto e decisão são formas nas quais pode moldar-se uma decisão regulamentar ou uma decisão individual. Um decreto é regulamentar quando fixa uma regra geral, é individual quando visa uma pessoa individualmente designada"; RIVERO. Direito administrativo, p. 80.

${ }^{7}$ BINENBOJM, Gustavo. Uma Teoria do Direito Administrativo: direitos fundamentais, democracia e constitucionalização. $2^{\mathrm{a}}$ ed. Rio de Janeiro: Editora Renovar, 2008, p. 285.
} 
poder regulamentar, entre os poderes da Administração, como provavelmente "sua potestade mais intensa e grave, posto que implica participar na formação do ordenamento 9 ".

Como um ponto inicial na caminhada de propor a rediscussão do regulamento de execução, há logo de se refutar o mito referente à existência de atos normativos, de qualquer grau que seja, que não inovem na ordem jurídica. Somente assim se poderá, honestamente, delinear seus limites diante do real conteúdo do que se entende por "fiel execução de leis", expressão elencada no já mencionado artigo 84, inciso IV, da Constituição da República.

Em outra ponta, é preciso introduzir que se convencionou também inserir os apelidados regulamentos autônomos no conteúdo abrangido pelo conceito de poder regulamentar.

Os regulamentos autônomos são aqueles que têm fundamento imediato no texto constitucional, o qual delimita uma esfera de conteúdos reservados ao regulamento $^{10}$. Não têm como fim viabilizar a execução de lei, pois não se apoiam em qualquer lei. Desse modo, qualificam-se como atos normativos primários.

Sempre houve alguma resistência no Brasil quanto à existência dessa espécie regulamentar, principalmente com o advento da Constituição de 1988, que, em seu texto original, parecia não o prever, ainda que implicitamente. Sobretudo porque, diante do necessário rompimento com a tradição autoritária, em que legislar por decreto representava algo banal e fora de qualquer limite, o novo regime constitucional resgatou o princípio da legalidade ao seu patamar máximo. Legalidade e legitimidade se tornaram, assim, sinônimos.

\footnotetext{
${ }^{8}$ ARAGÃO, Alexandre Santos de. Curso de direito administrativo. Rio de Janeiro: Forense, 2012, p. 34.

${ }^{9}$ ENTERRÍA, Eduardo García de; FERNÁNDEZ, Tomás-Ramón. Curso de direito administrativo. Tradução de Arnaldo Setti. São Paulo: Editora Revista dos Tribunais, 1990, p.198.

${ }^{10}$ cf. CYRINO, André Rodrigues. O poder regulamentar autônomo do Presidente da República: a espécie regulamentar criada pela EC nº 32/2001. Belo Horizonte: Fórum, 2005, p. 94.
} 
Passado o primeiro momento de redenção do Parlamento e da própria lei em si, observou-se que ainda que o apego íntimo à legalidade possa cumprir razoavelmente bem a função de controlar o arbítrio do Executivo, este não poderia estar atado em qualquer circunstância aos rigores de um processo legislativo. E, igualmente, a função da lei - aqui entendida como o Poder Legislativo - não se esgota em conter os abusos de um outro poder, principalmente em ambientes estabilizadamente democráticos, em que o próprio Poder Executivo também se imbui de legitimidade democrática.

Desse modo, a Emenda Constitucional número 32, promulgada em 11 de setembro de 2001, entre outras mudanças, veio a alterar a redação original do artigo 84 da Constituição, prevendo hipótese, à primeira vista inquestionável, de edição de decreto autônomo para dispor sobre organização e funcionamento da Administração Pública. O que anteriormente deveria ser feito "na forma da lei", prescindiria a partir de então de tal condição, tratandose de verdadeira exceção ao princípio da universalidade temática legislativa.

Por não se tratarem especificamente de regulamentos que executam ou complementam leis, mas, como dito, retiram seu fundamento de validade diretamente da Constituição Federal naqueles casos específicos elencados no artigo 84, inciso VI, alínea $a^{11}$, seria possível questionar a opção metodológica de agrupá-los no conceito tradicional de poder regulamentar, visto que, como já se pode observar, partem as espécies de pressupostos diferentes, também se diferenciando seu conteúdo, limites e formas de controle.

De fato, conquanto o instituto do regulamento autônomo ainda esteja tendo os seus contornos delineados pela doutrina, o adequado talvez fosse separá-lo como uma prerrogativa nova e específica da Administração Pública, ainda inserta na competência normativa. No caso brasileiro, o poder de,

\footnotetext{
${ }^{11}$ De acordo com o referido artigo, compete ao Presidente da República (a norma é aplicável aos três níveis de governo, conforme o princípio da simetria), dispor, mediante decreto, sobre "organização e funcionamento da administração federal, quando não implicar aumento de despesa nem criação ou extinção de órgãos públicos”.
} 
abstraindo-se de qualquer lei específica, estatuir a respeito da sua própria organização e funcionamento, o que, como se verá, não é pouco. Entretanto, por inegavelmente se ajustar ao conceito empreendido por Jean Rivero, aqui será enquadrado em uma perspectiva ampla de poder regulamentar, sendo, inclusive, abordado como uma das grandes novidades presentes no instituto.

Todo o estudo referente à capacidade normativa da Administração Pública, especialmente quanto à edição de regulamentos, está envolto ao âmbito de interpretação e acomodação de dois conhecidos princípios constitucionais: o princípio da separação de poderes e o princípio da legalidade.

Marcello Caetano, abordando o fundamento teórico do poder regulamentar da Administração Pública, ainda que, no caso, restrito ao tradicional regulamento de execução, indaga:

"Como é que, dentro da doutrina clássica da separação de poderes, se explica que a Administração Pública não se limite a actos individuais de execução das leis e promulgue normas gerais de conduta, embora secundárias? ${ }^{12,}$.

Hoje, esse questionamento se alarga, abrindo o Direito Administrativo a investigações e desafios ainda maiores: como pode hoje essa mesma Administração, além de promulgar normas gerais de conduta de caráter secundário, também deter competências regulamentares fundadas diretamente da Constituição, em uma zona que se promete alheia à da lei?

Para descobrir as novas feições do regulamento em si e do poder regulamentar, é preciso, então, compreender as mudanças pelas quais passa o Direito Administrativo contemporâneo, e, a seguir, conhecer o que se entende hoje por separação de poderes e legalidade.

12 CAETANO, Marcello. Princípios fundamentais do direito administrativo. Coimbra: Almedina, 1996, p. 81. 


\section{CAPÍTULO 1 - NOVOS PARADIGMAS DO DIREITO ADMINISTRATIVO}

\subsection{A concepção de paradigma}

A ideia de paradigma como conceito científico remonta a tradicional obra do americano Thomas Kuhn. Trata-se da consagrada "A estrutura das revoluções científicas". A inserção de inovadoras ideias no meio acadêmico à época de suas primeiras edições promoveu uma verdadeira revolução no modo de se fazer ciência ${ }^{13}$, de modo que, admitindo aqui a falta de originalidade, não são poucos artigos, teses e livros que se iniciam com alguma referência ao físico e filósofo americano.

O fato é que uma das principais ideias elencadas por Kuhn gira em torno de uma afirmação que, em verdade, ganhou vida própria: a de que as revoluções científicas não se produzem normalmente por simples acumulação de saberes, mas por uma ruptura na estrutura do conhecimento até então estabelecido.

Trata-se da mudança de paradigmas, entendidos estes como "realizações cientificas universalmente reconhecidas que, durante algum tempo, fornecem problemas e soluções modelares para uma comunidade de praticantes de uma ciência $^{14,}$.

Compreendendo que a vigência de certo paradigma está fielmente representada a partir de determinadas premissas, nas quais se apoiam todo um sistema de conhecimento, as revoluções são momentos em que se acumulam as contradições e incompreensões dentro de um próprio paradigma, gerando questionamentos e teorias alternativas ao próprio modelo.

\footnotetext{
${ }^{13}$ Que, não por acaso, deram azo à inclusão de um posfácio a partir da edição de 1969 da obra, em que o autor estabelece o que, enfim, quer dizer quando trabalha com o termo 'paradigma'.

${ }^{14}$ KUHN, Thomas S. A estrutura das revoluções científicas. Tradução de Beatriz Vianna Boeira e Nelson Boeira. $3^{\text {a }}$ ed. São Paulo: Editora Perspectiva, 1991, p. 13.
} 
São fases que "põem em xeque a sua legitimidade e propõem novas formas de conceber o objeto e a própria metodologia de trabalho da ciência ${ }^{15}$ ".

Diante de tal circunstância, surge a noção de rompimento de paradigmas, abrindo portas ao surgimento de novas teses que, se capazes de criarem consenso na comunidade científica, fincam-se como novos modelos de compreensão do sistema.

Crê-se, sem qualquer entusiasmo barato, que este é um momento pelo qual passa o Direito Administrativo no Brasil, ainda que não de simples visualização e de tormentoso desenvolvimento.

\subsection{A evolução do Direito Administrativo brasileiro}

O reconhecimento da força normativa da Constituição, hoje parâmetro de atuação direta do administrador, legislador e juiz, e igualmente de inegável aplicabilidade nas relações privadas, já há algum tempo é tratado com louvores na doutrina jurídica nacional e internacional.

De fato, a chamada constitucionalização do Direito, fruto do movimento conhecido por neoconstitucionalismo, "importa na irradiação dos valores abrigados nos princípios e regras da Constituição por todo o ordenamento jurídico ${ }^{16,}$,

Nas palavras do professor catedrático de Direito Constitucional da Universidad Complutense de Madrid, Carlos de Cabo Martín ${ }^{17}$, ocorre atualmente a revalorização do Direito, agora a partir da Constituição, de maneira que a luta pelo Estado de Direito se assume e se utiliza de outras abordagens para a consecução dos valores consagrados pela sociedade. Essa

\footnotetext{
${ }^{15}$ BINENBOJM, Gustavo. Uma Teoria do Direito Administrativo, p. 28.

${ }^{16}$ BARROSO, Luis Roberto. Neoconstitucionalismo e Constitucionalização do Direito - O triunfo tardio do Direito constitucional no Brasil, in Revista eletrônica sobre a reforma do Estado, Salvador, edição número 9, Instituto brasileiro de Direito Público, 2007. Disponível na internet: <http://www.direitodoestado.com.br/redae.asp>. Acesso em 11/09/2013.

${ }^{17}$ CABO MARTín, Carlos de. Sobre El Concepto De Ley. Madrid: Trotta, 2000, p. 12.
} 
luta pelo Estado de Direito, personificada pela Constituição, se torna arma crítica e veículo transformador.

Os reflexos desta onda de mudanças atingem profundamente as bases do direito infraconstitucional, de modo que há uma gama imensa de autores ${ }^{18}$ que, em seus estudos, buscam enunciar, por exemplo, o conteúdo do "Direito CivilConstitucional" ou o significado da "constitucionalização do Processo Penal".

De todo modo, se é verdade que todo ordenamento jurídico nacional passa por tais reconfigurações desde o advento da Constituição de 1988, reflexos da chamada filtragem constitucional ${ }^{19}$, é bem real que o Direito Administrativo não foi um dos primeiros campos a internalizar a necessidade de se oxigenar a partir da nova carta constitucional. É possivel cogitar alguns motivos para tanto.

Em primeiro lugar, por se tratar de uma matéria umbilicalmente ligada à prática política, de modo que, embora esteja reconhecido há séculos como campo jurídico autônomo ${ }^{20}$, seus institutos, premissas e princípios refletem muitas vezes visões pragmáticas do cotidiano estatal, nem sempre abertas a inovações jurisprudenciais e elaborações doutrinárias.

Como concepção quase caricata dessa constatação, está a declaração de um grande administrativista brasileiro, Adilson Abreu Dallari, atribuindo a Hely Lopes Meirelles, com quem trabalhou por certo tempo, a noção de que "o Direito não foi feito para atrapalhar a Administração ${ }^{21}$. Carlos Ari Sundfeld,

18 A esse respeito, v. SOUZA NETO, Cláudio Pereira de; SARMENTO, Daniel (coord.). A Constitucionalização do Direito: fundamentos teóricos e aplicações específicas. Rio de Janeiro: Lumen Juris, 2007.

${ }^{19}$ No tocante ao fenômeno chamado filtragem constitucional, v. SCHIER, Paulo Ricardo. Filtragem Constitucional: construindo uma nova dogmática jurídica. Porto Alegre: Sérgio Antonio Fabris Editor, 1999.

${ }^{20} \mathrm{Na}$ lição de Jean Rivero sobre o histórico desde o nascedouro do Direito Administrativo, "Na França, o direito administrativo é não só um direito distinto, definido por objeto próprio, mas direito autônomo, fundado em princípios próprios, originais. Em relação ao "direito comum", ele é "derrogatório". Não se contenta em considerar problemas não propostos em direito privado, mas resolve-os, socorrendo-se de noções que o direito privado ignora (utilidade pública, potestade pública)". RIVERO, Jean. Curso de Direito Administrativo Comparado. Tradução de J. Cretella Jr. $2^{\mathrm{a}}$ ed. São Paulo: Editora Revista dos Tribunais, 2004, p. 63.

${ }^{21}$ SUNDFELD, Carlos Ari. Direito administrativo para céticos. São Paulo: Malheiros, 2012, p. 96. 
em frase igualmente curiosa e não menos representativa da tradição pragmática dos administrativistas, aponta:

"A grande maioria dos especialistas em direito administrativo é boa em evitar confusão - conte com eles para isso -, mas você terá que buscar alguém meio fora da curva se quiser ajuda para pensar coisas realmente novas ${ }^{22,}$.

Ocorre que, embora o pragmatismo e o conservadorismo, inclusive como métodos de autodefesa em relação aos órgãos de controle, ainda reinem no dia-a-dia dos especialistas na matéria, também o Direito Administrativo vem cedendo à aproximação entre o ser e o dever ser constitucional, de modo que a constitucionalização do direito vem possibilitando o surgimento de novas leituras de conceitos e institutos tradicionais no campo administrativo.

Aqui, surge outro problema: ainda que se acabe reconhecendo, quase unissonamente, essa premente necessidade de se revigorar alguns fundamentos do Direito Administrativo tradicional, a própria doutrina não converge em apontar inequivocamente o objeto principal da mudança de paradigma.

Diogo de Figueiredo Moreira Neto, em uma de suas obras mais recentes $^{23}$, indica o que seriam para si os "quatro paradigmas do direito administrativo pós-moderno". Debruça-se autor sobre a) legitimidade; b) finalidade; c) eficiência; d) resultados. Sem se pretender resenhar de maneira superficial a obra do referido autor, é preciso abordar de que modo tais princípios serviriam de base para se compreender um Direito Administrativo contemporâneo.

Primeiramente, ao tratar da legitimidade, o autor a relaciona com a consagração do Estado Democrático de Direito. Enquanto a noção de Estado de Direito, puramente, remeteria à legalidade clássica, a qualificação de "democrático" daria o suporte necessário para reconhecer a necessidade de um

\footnotetext{
${ }^{22}$ SUNDFELD, Carlos Ari. Direito administrativo para céticos, p. 38.

${ }^{23}$ MOREIRA NETO, Diogo de Figueiredo. Quatro paradigmas do direito administrativo pósmoderno: legitimidade: finalidade: eficiência: resultados. Belo Horizonte: Fórum, 2008.
} 
Estado não apenas fundado em um sistema juridicamente fechado e procedimentalmente formalista, mas naquele legitimamente sustentado. $\mathrm{Ou}$ seja, um Estado que tem como fim imediato a consagração de valores próprios da pessoa humana e de valores próprios da organização política, baseados estes, agora, em uma liberdade contratual formal, superando a visão legalista do poder.

"Eis porque o Direito pós-positivista e pós-moderno, que se vai a estruturar a partir de meados do século XX, ao sobrepor o fundo à forma e a legalidade à legitimidade, recupera os valores em todas as fases de realização do Direito - tanto na sua criação, seja parlamentar ou não, como na sua aplicação, seja privada, administrativa ou judicial, desenvolvendo-se em função dessa reversão, uma nova idéia do próprio Direito e, deinde, uma nova idéia aplicativa, como uma nova hermenêutica ${ }^{24,}$ (os grifos são do autor).

O paradigma da finalidade, por sua vez, nascendo como consequência do fator legitimidade, aponta para o deslocamento do eixo juspolítico do poder, partindo do Estado, tradicional único protagonista das grandes decisões políticas, para a Sociedade, reconhecendo-se o primado da pessoa e do coletivo social privado ${ }^{25}$.

Já as noções de eficiência e resultados, aqui tratadas de modo conjunto, expressam, primeiramente, a necessidade de uma teoria funcional do direito público. Assim, o Estado que age por meio de ritos pré-definidos, como o ato administrativo e o contrato administrativo, deve ser flexibilizado para que seja cultivado o resultado eficiente como norte da atuação administrativa em geral. Privilegiar a funcionalidade seria justamente endereçar prioritariamente a atuação ao atingimento da eficiência.

\footnotetext{
${ }^{24}$ MOREIRA NETO, Diogo de Figueiredo. Quatro paradigmas do direito administrativo pósmoderno, p. 41-42.

${ }^{25}$ MOREIRA NETO, Diogo de Figueiredo. Quatro paradigmas do direito administrativo pósmoderno, p. 76.
} 
Como indica o próprio autor ${ }^{26}$, as consequências desse novo modo de agir não são poucas, implicando abalos nas teorias tradicionais das nulidades, da formalidade e até sobre o próprio conteúdo do que se entende por competência, por exemplo.

Em outra direção, acaba-se garantindo, desse modo, a administração de resultados, fruto do caráter gerencial hoje propugnado a partir das reformas de Estado, ideia sucessora da administração burocrática, de inspiração weberiana.

Trata-se, enfim, da referência a um agir administrativo voltado ao resultado legítimo e eficiente e não apenas a processos administrativos legítimos e eficientes, e muito menos ainda a atos administrativos singulares legítimos e eficientes ${ }^{27}$, que, por outro lado, poderiam ser suficientes caso bastasse o paradigma da legitimidade.

Outros autores, ao tratarem das mudanças recentes pelas quais vem passando o Direito Administrativo, acentuam sobremaneira exatamente esse possível novo paradigma com o qual tem que lidar a Administração Pública: a perseguição dos resultados como grande fundamento de sua atuação.

Assim é que Carlos Ari Sundfeld elabora a chamada teoria dos antagonismos $^{28}$, a partir da qual caracteriza o Direito Administrativo dos Clips como aquele representativo da administração pública tradicional e burocrática. Estaria nesse campo o chamado "Direito dos Institutos", isto é, a supervalorizada prática dos administrativistas de moldar e interpretar institutos, como o ato administrativo, o contrato e o convênio, em contraposição ao real conteúdo e finalidade de cada ação administrativa concretamente analisada.

\footnotetext{
${ }^{26}$ MOREIRA NETO, Diogo de Figueiredo. Quatro paradigmas do direito administrativo pósmoderno, p. 111.

${ }^{27}$ MOREIRA NETO, Diogo de Figueiredo. Quatro paradigmas do direito administrativo pósmoderno, p. 136.

${ }^{28}$ Sobre o tema, v. SUNDFELD, Carlos Ari. O Direito Administrativo entre os clips e os negócios, in Revista de Direito Público da Economia. Belo Horizonte, ano 5, n. 18, abr. 2007.
} 
Por outro lado, indica Sundfeld a emergência cada vez mais plena do Direito Administrativo dos Negócios, buscando minimizar a preocupação com os aspectos formais da atividade da máquina pública em face aos resultados que dela se espera - ou pelo menos se deveria esperar, tendo em vista também a elevação do princípio geral da economicidade.

O grande mérito do autor, entretanto, está em perceber, argutamente, que o Direito Administrativo dos Negócios não deve substituir de modo completo e automático o modelo burocrático tradicional, senão completar espaços em que a eficiência deva ser perseguida de modo mais claro. Nas palavras de Sundfeld,

"Na Administração Pública o ambiente mais propício ao DAN é o dos organismos que disputam mercado (empresas estatais que concorrem com empresas do setor privado) ou que são responsáveis por serviços cuja falta ou deficiência possa levar à convulsão popular imediata (transporte público, segurança, coleta de lixo) ou a perdas eleitorais (saúde, educação, financiamento agrícola etc). Também os momentos de crise econômica e política aguda são adequados para ela. Aí, são muito fortes os estímulos para a busca de resultados ${ }^{29}$.

E conclui:

“(...) não se pode ignorar o caráter bipolar do direito administrativo, tomando um só polo como dogma e lançando o outro às feras. A militância em torno da bandeira do direito administrativo dos clipes teve um papel importante, mas está virando religião monoteísta em guerra santa. $\mathrm{O}$ direito administrativo dos negócios não é invenção recente de mentes deturpadas, mas parte necessária da história e da prática do direito administrativo. Talvez estejam nele algumas das soluções para os impasses governamentais recentes e para fazer de nosso ramo o direito administrativo do desenvolvimento que tanto se reclama ${ }^{30,}$.

Em outra via de análise, certos autores reforçam como grande novidade no Direito Administrativo a elevação dos canais de participação popular ${ }^{31}$.

\footnotetext{
${ }^{29}$ SUNDFELD, Carlos Ari. Direito administrativo para céticos, p. 88.

${ }^{30}$ SUNDFELD, Carlos Ari. Direito administrativo para céticos, p. 92.

31 Para uma análise a respeito do âmbito aplicação e conteúdo do denominado princípio da participação, v. GARCÍA ENTERRÍA, Eduardo; FERNÁNDEZ, Tomás-Ramón. Curso de direito
} 
Nessa perspectiva, Agustín Gordillo, embora obviamente sem abordar especificamente a realidade brasileira, remonta o que seriam para si os novos paradigmas do Direito Administrativo global: além das ideias de a) consenso e adesão, e b) motivação ou explicação, também ressalta o autor a consagração da c) participação administrativa ${ }^{32}$.

Em uma das teses acadêmicas mais impactantes da última década na matéria, Gustavo Binenbojm destaca quatro tendências do Direito Administrativo contemporâneo, que seria para si o Direito Administrativo constitucionalizado.

Ressalta o autor a elevação do princípio da juridicidade, como decorrência da crise da lei formal e do princípio da legalidade. Nesse sentido, reforça que a lei está deixando de ser o único e último fundamento da atividade administrativa $^{33}$. Tal aspecto oferece relevo à função normativa do Poder Executivo, especialmente em seu mister de interpretar e aplicar a Constituição.

Sundfeld, novamente preciso, sintetiza perfeitamente o fundamento dessa virada: "Do ponto de vista estritamente técnico, a sacralização da lei não é necessária ao direito administrativo, isto é, não é indispensável ao sucesso do projeto de condicionar juridicamente a Administração ${ }^{34, "}$

Prosseguindo, Binenbojm revisita a tradicional dicotomia entre ato vinculado versus ato discricionário, indicando que, em verdade, há graus de vinculação à juridicidade. Ao traçar um panorama histórico a respeito do que sempre se entendeu por discricionariedade, o autor observa que, superada a fase de total liberdade oferecida ao administrador, hoje se solidifica a tese de que os atos administrativos poderão ser, além de juridicamente vinculados por

administrativo, p.799-811. A obra dos autores espanhóis é resgatada também em BAPTISTA, Patrícia. Transformações do direito administrativo. Rio de Janeiro: Editora Renovar, 2003, p. 172.

${ }^{32}$ GORDILLO, Agustín. Tratado de Derecho Administrativo. $8^{a}$ ed. Buenos Aires: Fundación de Derecho Administrativo, 2003. Tomo I, p. II-14.

${ }^{33}$ BINENBOJM, Gustavo. Uma Teoria do Direito Administrativo, p. 126.

${ }^{34}$ SUNDFELD, Carlos Ari. Direito administrativo para céticos, p. 143. 
regras ou conceitos jurídicos indeterminados, também vinculados por princípios constitucionais.

Em tema circunscrito por farta polêmica na doutrina administrativista, o autor reforça uma terceira tendência do Direito Administrativo e da estrutura da Administração Pública hodierna: a ruptura com a tradição da organização piramidal do Poder Executivo, destacando, nessa esteira, o surgimento de autoridades administrativas independentes cuja atuação não seria imediatamente orientada às escolhas políticas do governo. Em virtude disso, tais entidades deteriam - e detêm, de fato - uma autonomia amplamente reforçada ${ }^{35}$. Trata-se da mais que debatida atuação das agências reguladoras.

Por fim, em tópico não menos polêmico, o autor contesta o histórico princípio da supremacia do interesse público. Aponta Binenbojm, sustentado por outros autores de renome ${ }^{36}$, duas principais objeções ao mencionado princípio.

Primeiramente, questiona a ideia de prevalência apriorística de um princípio, já que a teoria mais atual das normas jurídicas, em casos de conflitos entre princípios, ensina a necessidade de aplicação do mecanismo da ponderação. Nesse caso, não faria sentido a existência de um princípio que preconizaria previamente a supremacia de um valor. Sobre tal condição, o autor defende ter sido o princípio historicamente usado como instrumento de exercício arbitrário da discricionariedade administrativa ${ }^{37}$.

No mesmo raciocínio, é ressaltado que o interesse público não necessariamente será coincidente com o interesse estatal, ou mesmo com um interesse coletivo eventualmente em jogo. Ou seja, a qualificação de determinado interesse como interesse público só poderá ser feito, de acordo com a argumentação expendida, após um juízo de ponderação, de modo que

\footnotetext{
${ }^{35}$ BINENBOJM, Gustavo. Uma Teoria do Direito Administrativo, p. 245.

${ }^{36}$ Sobre o tema, confira-se: SARMENTO, Daniel (coord.). Interesses públicos vs. Interesses privados: desconstruindo o princípio da supremacia do interesse público. Rio de Janeiro: Lumen Juris, 2005.

${ }^{37}$ BINENBOJM, Gustavo. Uma Teoria do Direito Administrativo, p. 87.
} 
seria perfeitamente normal em determinado caso um interesse particular se configurar como o interesse público a ser buscado ou preservado pelo administrador.

Após tudo o que já foi apresentado, vê-se que variam os enfoques dados a respeito do conteúdo da constitucionalização do Direito Administrativo brasileiro.

Entretanto, ainda que haja forte resistência de parte tradicional da doutrina administrativista em acatar algumas das proposições colocadas ${ }^{38}$, as teses acima expostas a consagrar um novo Direito Administrativo poderiam ser reduzidas a algumas poucas asserções, suficientemente compatíveis entre si: a) a crescente valorização dos direitos fundamentais da pessoa humana, vistos como o principal norte da atuação administrativa; b) a flexibilização da noção de potestade pública; c) a emergência do princípio da juridicidade; d) a maior busca por eficiência; e) e por participação administrativa.

E de fato, dentre todas essas tendências, ao menos uma dificilmente pode ser contestada, consolidando-se aos poucos como uma verdadeira mudança de paradigma no Direito Administrativo: a elevação do principio da juridicidade, em substituição à legalidade clássica, como parâmetro de atuação do administrador.

Tal substituição, entre outras consequências, promove de modo singular uma reconfiguração da função normativa do Poder Executivo, na qual se insere o poder regulamentar, como já delineado. Assim sendo, também não poderia deixar de abalar as bases e conteúdo do que se convencionou chamar por

\footnotetext{
${ }^{38}$ São simbólicas duas grandes críticas. Primeiramente, a de Celso Antônio Bandeira de Mello à recepção do modelo estrangeiro de agências reguladoras e a concepção de administração policêntrica: "no que atina às agências reguladoras, ao que parece criadas para atender a exigências dos investidores estrangeiros, constituem-se em instituto que não se acomoda bem ao direito brasileiro e que, do modo como foram reguladas, incorrem, além disto, em inconstitucionalidade", BANDEIRA DE MELLO, Celso Antônio. Curso de direito administrativo. 26a ed. São Paulo: Malheiros, 2009, p. 1060. Em segundo lugar, à suposta derrocada do princípio da supremacia do interesse público. Defendendo a subsistência do referido princípio, veja-se, dentre outros: DI PIETRO, Maria Sylvia Zanella. O princípio da supremacia do interesse público: sobrevivência diante dos ideais do neoliberalismo. In:
} 
principio da separação de poderes. Tais temas serão objeto do capítulo seguinte.

Maria Sylvia Zanella Di Pietro; Carlos Vinícius Alves Ribeiro. (Org.). Supremacia do interesse público e outros temas relevantes do direito administrativo. São Paulo: Atlas, 2010. 


\section{CAPÍTULO 2 - A REVIGORAÇÃO DOS FUNDAMENTOS TEÓRICOS DE UM PODER REGULAMENTAR}

\subsection{Lei, legalidade e juridicidade}

Há certo traço de trivialidade em se falar em crise da lei formal. A emergência da juridicidade, o desprestígio da lei são expressões já fartamente utilizadas no meio acadêmico e até mesmo na prática jurídica atual. Se essa é uma verdade empiricamente observável, é preciso que se foque em determinar

o contexto histórico correlato e seus fundamentos propiciadores. É preciso relembrar que há uma separação indissociável entre o poder regulamentar e o princípio da legalidade, de modo que abordar as novas feições da competência regulamentar - e normativa, em geral, da Administração - é tratar de formas em que se a legalidade, em caráter amplo, se manifesta no ordenamento jurídico.

Não obstante o conceito de lei tenha percorrido grandes eras, sendo uma manifestação verdadeiramente milenar, não há dúvida de que a sua consagração se dá a partir do século XVII, com o movimento iluminista e a crítica deste ao ancien régime. Como será tratado no próximo capítulo, é principalmente a partir da sistematização de uma divisão de poderes que se possibilita pensar em uma função própria para a lei, que a partir de então deveria ser elaborada por um órgão próprio de Estado, inconfundível com o monarca - ou simplesmente com quem deve aplicá-la.

A construção da lei como o mito que sobrevive até os tempos atuais tem, de igual modo, como grande mola impulsora a soberania popular, fundada na escola contratualista, especialmente decorrente da obra de Rousseau. E é, de 
fato, a crítica e revisão do contratualismo clássico e de seu fundamento racionalista que possibilitam um novo olhar sobre a lei ${ }^{39}$.

A ruína da razão é ponto-chave na construção da filosofia contemporânea - ou, ao menos, pós-moderna, donde ascenderam escolas como as da fenomenologia e estruturalismo. Em outra via, especialmente a partir da consagração da vertente psicanalítica, a psicologia tradicional cede à progressiva assimilação do papel do inconsciente na modelagem do indivíduo, de onde se constata a fragilidade das bases puramente racionais de institutos sociais e jurídicos ${ }^{40}$.

Diante dessas abordagens, para fundamentar as recentes mudanças pelas quais passa o conceito de lei, Carlos de Cabo Martín se aproxima de motores de duas origens: primeiramente, externos ao ordenamento jurídico. Nesse ponto, em primeiro lugar, o autor insere justamente o declínio da crença racionalista. Cabo Martín não vacila em sugerir que o conceito de lei, com seu caráter de representação geral e dotado dos atributos de abstração e objetividade, está fora de sintonia com o momento cultural contemporâneo, o pós-modernismo. É uma realidade afirmar que há um momento de fragmentação jurídica, decorrente da valorização cada vez maior do concreto, empírico e subjetivo nas ciências humanas ${ }^{41}$.

O autor espanhol ainda trata de outras duas influências externas ao plano jurídico a modelar o processo de transformação da lei. Além da quebra de seus pressupostos culturais - com os argumentos acima expostos - é

\footnotetext{
${ }^{39}$ É possível dizer, isto posto, que a aura de racionalidade que até hoje é apontada como elemento caracterizador da ciência jurídica repousaria sobre um jogo de crenças mais profundas, de que seria testemunha a mística que acompanha a lei. Nesse sentido, v. CHEVALLIER, Jacques. O Estado pósmoderno. Tradução de Marçal Justen Filho. Belo Horizonte: Fórum, 2009, p.118.

${ }^{40}$ É de grande valia, de fato, o resgate de conceitos oriundos da psicanálise: "Ao atribuir à pulsão, ao inconsciente e ao fantasma um lugar fundamental no psiquismo, o discurso freudiano colocou os registros do pensamento e da vontade subsumidos a esses outros registros psíquicos. Promoveu, assim, o descentramento do sujeito, dos registros do eu e da consciência, de maneira a renovar a crítica ao livre-arbítrio da razão e do pensamento. O cogito cartesiano, enfim, foi desalojado da sua posição primordial”. Os grifos são do próprio autor; BIRMAN, Joel. O sujeito na contemporaneidade. Rio de Janeiro: Civilização Brasileira, 2012, p. 129.

${ }^{41}$ CABO MARTÍN, Carlos de. Sobre El Concepto De Ley, p.74.
} 
rememorado o enfraquecimento da sua base instrumental, eis que o pluralismo vigente na sociedade contemporânea exige crescentemente soluções consensuais e abertas na regulação de conflitos. Há, assim, uma tendência de fuga as instituições tradicionais, como o rígido modelo da solução legal para a conformação de situações em sociedade. Por último, ressalta Cabo Martín a fadiga dos pressupostos legitimadores da lei, pontuando, entre outros aspectos, a crise de representatividade do Parlamento ${ }^{42}$.

No que concerne às causas internas ao ordenamento jurídico que amoldam o novo papel da lei, o autor apresenta dois pontos de cunho fundamental para a discussão ora examinada: inicialmente, o advento da normatividade constitucional, relativizando a autonomia e supremacia da lei, que deve se conformar aos fins erigidos pelo constituinte. Tal circunstância, aliada à progressiva extensão do âmbito de proteção e aplicação da Constituição, gera, igualmente, a ascensão institucional do Judiciário, mais especificamente na jurisdição constitucional ${ }^{43}$. Ou seja, questões relevantes em sociedade são cada vez mais decididas em última instância pelo Judiciário, observando-se processo de transferência de poder em prejuízo das instâncias políticas tradicionais ${ }^{44}$.

Já a outra influência interna ao ordenamento jurídico que determinaria o enfraquecimento da lei seria a crescente atividade normativa da Administração $^{45}$, exigência necessária na sociedade moderna diante de algumas variáveis, como a erupção do Estado social e regulador.

Gustavo Binenbojm lista também o que percebe como motivos fundamentais para a crise da lei formal, realçando algumas peculiaridades do caso brasileiro. Trata o autor, como primeira razão, da inflação legislativa observada principalmente nos países de tradição romano-germânica, fator que

\footnotetext{
${ }^{42}$ CABO MARTÍN, Carlos de. Sobre El Concepto De Ley, p.75-78.

${ }^{43}$ CABO MARTÍN, Carlos de. Sobre El Concepto De Ley, p.79.

${ }^{44}$ Cf. BARROSO, Luís Roberto. O controle de constitucionalidade no direito brasileiro. $5^{a}$ ed. São Paulo: Saraiva, 2011, p. 360.
} 
teria banalizado o fenômeno da lei $^{46}$. Em sequência, Binenbojm demonstra como irrefutável o fato que os critérios formais de validade do direito (no caso, a lei) acabaram por legitimar as maiores injustiças do século $\mathrm{XX}$, que foram as práticas nazifascistas. Nem sempre serviriam, assim, ao bem comum, como na concepção rousseauniana $^{47}$.

Como terceira razão propiciadora do esvaziamento da lei, indica que esta teria deixado de ser a principal e mais importante forma de manifestação da vontade geral do povo ${ }^{48}$. Refere-se, assim, ao fenômeno do constitucionalismo associado à normatividade constitucional, observados por Carlos de Cabo Martín. Além disso, Binenbojm trata da progressiva criação de atos normativos infraconstitucionais, diversos da lei, a fundamentar a atuação administrativa, como as medidas provisórias e os regulamentos autônomos. Em último lugar, aborda-se o fenômeno do presidencialismo de coalizão, percebido no sistema brasileiro, que deslegitimaria em grande parte a atuação do Legislativo.

É de se notar que muito embora estes autores reforcem a existência de uma crise de representatividade do Parlamento em geral, parece não ser apropriado estender o declínio da lei formal ao esvaziamento do papel das casas legislativas. É válido reafirmar a indiscutível importância de outras funções típicas do Poder Legislativo, como o dever de fiscalização, em especial por meio das Comissões Parlamentares de Inquérito, assim como a própria função de representação de minorias, através das discussões e participações em comissões temáticas.

De todo modo, voltando ao fenômeno da lei, se esta, do histórico de autoridade que sempre gozou, sofre hoje com transformações sociais, culturais e jurídicas que lhe retiram profundamente a supremacia anteriormente

\footnotetext{
${ }^{45}$ CABO MARTÍN, Carlos de. Sobre El Concepto De Ley, p. 85.

${ }^{46}$ BINENBOJM, Gustavo. Uma Teoria do Direito Administrativo, p. 128.

${ }^{47}$ BINENBOJM, Gustavo. Uma Teoria do Direito Administrativo, p. 129.

${ }^{48}$ BINENBOJM, Gustavo. Uma Teoria do Direito Administrativo, p. 130.
} 
observada, é lógico concluir que o princípio da legalidade administrativa está sendo repensado em exata proporção.

O princípio da legalidade, em sua relação com a Administração Pública, por muito tempo se traduziu na vinculação positiva à lei, ou seja, na ideia de que a Administração só poderia agir quando o ato estivesse previsto em lei - e, se estivesse, atuando exatamente como definido no parâmetro legal. Fundamentava-se essa construção precisamente no caráter sagrado que detinha a lei. Passada a era da arbitrariedade e dos privilégios, nada mais razoável, baseando-se no contratualismo iluminista, que toda a esfera de atuação do Executivo estivesse cingida à lei.

Dessa noção, surgem conceitos como o de que administrar seria aplicar a lei de ofício, bem como a concepção disseminada de regulamentos como meros atos secundários a executar fielmente à lei, longe de qualquer possibilidade de inovação no mundo jurídico.

É possível perceber, de plano, que essa tentativa de limitação e controle da Administração Pública acabou descambando para um formalismo ideológico. Tornou-se fetiche. O demasiado apego aos critérios formais de validade do direito não somente representou meio ineficaz para verificar a legitimidade da atuação do governante, bem como afigurou séria barreira de ineficiência diante da percepção de que o Estado contemporâneo deve buscar uma série de fins, muitas vezes não previstos em lei e até com ela conflitantes.

$\mathrm{Na}$ tentativa de construir uma concepção pós-positiva do princípio da legalidade, Alexandre Santos de Aragão consigna, de maneira resumida e convincente, que a total vinculação da Administração Pública à lei é inviável, por impedir qualquer margem de apreciação própria do administrador em um Estado que possui múltiplas e complexas atribuições, a serem exercidas com grande dinamismo ${ }^{49}$. Em verdade, ainda que tal fosse o intento, tal teoria nunca

\footnotetext{
${ }^{49}$ ARAGÃO, Alexandre Santos de. A Concepção Pós- Positivista do Princípio da Legalidade. In Revista de Direito Administrativo, Rio de Janeiro, v. 236, abril/junho 2004, p. 52.
} 
seria experimentada por completo, pois não há, pragmaticamente, como impedir que o governante pondere, por exemplo, os melhores meios de aplicação da lei, diante da textura aberta de regras e da linguagem em geral. De modo que, ainda que não esteja contrariando a lei e a legalidade, sempre haverá margem de apreciação de quem trabalhe com normas.

O que se está a comprovar, desde este histórico referente ao princípio da legalidade e passando pelas tendências trazidas por Carlos de Cabo Martín a modelar o novo fenômeno da lei, é a emergência do princípio da juridicidade, com a respectiva valorização da função normativa do Poder Executivo.

O princípio da juridicidade iguala-se ao que muitas vezes foi denominado bloco de legalidade a amparar a atuação da Administração Pública. Ou seja, a atividade administrativa "não obedece a um esquema único, nem se reduz a um tipo de norma específica - a lei formal", mas é guiada pelo ordenamento jurídico como um todo, como uma unidade, que abarca "diferentes graus e distintos tipos de normas", tendo a Constituição como um "elo de unidade a costurar todo o arcabouço normativo que compõe o regime jurídico administrativo" $"$.

A partir da ascensão da juridicidade, fruto, assim, de uma vertente da constitucionalização do direito administrativo, a atuação da Administração terá como fundamento não apenas a lei, mas, em primeiro lugar, a Constituição. Diante da melhor promoção de direitos fundamentais e outros valores essenciais, como a eficiência, inclusive será lícito ao administrador ir além do que previu a lei que eventualmente lhe dê suporte.

\footnotetext{
50 BINENBOJM, Gustavo. Uma Teoria do Direito Administrativo, p. 141. Sobre o princípio da juridicidade, também conferir: OTERO, Paulo. Legalidade e Administração Pública - O sentido da vinculação administrativa à juridicidade. Coimbra: Almedina, 2003. É válido, a propósito, pontuar que também Paulo Otero cita, no processo de degeneração da legalidade, paradigmas clássicos que hoje se encontram subvertidos. Entre outros, destaca o autor português o mito positivista da perfeição da lei, a imagem de uma legalidade dotada de plenitude, a fé na ilimitada subordinação de toda a atividade administrativa aos esquemas formais definidos pela legalidade e a própria noção de centralidade do Estado enquanto única instituição pública soberana. Vide p. 137-263.
} 
Vê-se como inegável a maior importância da atividade normativa do Poder Executivo, que assumirá também maior responsabilidade na concretização dos princípios elencados na Constituição, explícita ou implicitamente.

Mas o crescente foco na competência normativa do Executivo não se esgota apenas a partir de sua incumbência de ser um dos intérpretes e aplicadores da Constituição. Ao alimentar e fundamentar a maior atividade normativa da Administração, o princípio da juridicidade se soma a outra percepção: a de que se torna cada vez mais necessária a regulação de certas áreas da sociedade por meio de atos alheios ao processo legislativo.

Fatores como a evolução tecnológica e científica, ao gerarem urgência e complexidade em temas cotidianos, exigem novas posturas do Poder Público ${ }^{51}$. Soluções legislativas raramente atendem adequadamente às exigências de uma sociedade cada vez mais técnica, veloz e conectada. A sociedade do risco impõe ao Estado o tratamento eficiente de situações que tenham como marca principal tais características, o que é visto, primordialmente, na seara econômica.

É por esse motivo que se fala que o advento do Estado social, ao atrair uma série de deveres e comportamentos anteriormente não exigíveis do Poder Público, e do Estado regulador, com a progressiva atividade de disciplina, fiscalização, ordenação e fomento do mercado, gerou uma ascensão institucional do Poder Executivo na elaboração de normas, como saída necessária tanto para a melhor consecução de políticas públicas quanto para a eficaz intervenção estatal no domínio econômico.

O expediente largamente utilizado para ajustar a partir daí o exercício normativo do Poder Executivo foi, principalmente, a elaboração de leis de baixa densidade normativa, dirigindo ao executor de políticas públicas ou ao 
regulador o tratamento infralegal, com alto grau de discricionariedade, de questões atinentes às suas funções ${ }^{52}$. Ao passo que vastas e importantes matérias entram na órbita do regulamento, e exatamente com tal nível de discricionariedade oferecido ao administrador, relativiza-se a concepção de legalidade relacionada à rigorosa vinculação das posturas administrativas a uma lei prévia, supostamente suficiente por si própria. Não há mais a onipresença da lei.

O poder regulamentar, exercido seja por meio das agências reguladoras ou pela tradicional atuação do Chefe do Executivo - a variar o contexto em que se encontre a matéria a ser normatizada - vê-se, então, reforçado, de modo que há quem diga que estamos vivendo na era da concorrência normativa ${ }^{53}$.

\subsection{A nova separação de poderes}

O princípio da separação de poderes nasce em sua concepção moderna com a noção atribuída a Montesquieu de que não haveria liberdade quando na mesma pessoa ou no mesmo corpo de magistratura o Poder Legislativo estivesse reunido ao Poder Executivo, pois, nesse caso, poder-se-ia esperar que esse monarca fizesse leis tirânicas para executá-las tiranicamente ${ }^{54}$. Observa-se dessa ideia alguns pontos fundamentais da obra de Montesquieu, que tanto foi abordada na ciência política e em todos os ramos do Direito Público.

\footnotetext{
51 vide GUERRA, Sérgio. Regulação e maleabilidade normativa à luz do direito administrativo econômico. In: FREITAS, Daniela Bandeira de; VALLE, Vanice Regina Lírio do (Coord.). Direito administrativo e democracia econômica. Belo Horizonte: Fórum, 2012, p. 232.

52 Utiliza-se o legislador, desse modo, cada vez mais de categorias como conceitos jurídicos interminados e princípios jurídicos, entendidos estes como normas de cunho imediatamente finalísticos, que não determinam diretamente uma conduta concreta a ser seguida. São fornecidos grandes standards, parâmetros de atuação ao administrador, o qual apenas no momento de regulamentação da norma definirá o seu conteúdo. É de se notar que se rejeita, aqui, a tese da deslegalização, defendida por muitos autores. Cite-se, por todos, SOUTO, Marcos Juruena Villela. Direito Administrativo Regulatório. $2^{\mathrm{a}}$ ed., Rio de Janeiro: Lumen Juris, 2005.

${ }^{53}$ SUNDFELD, Carlos Ari. Direito administrativo para céticos, p. 154.

${ }^{54}$ DALLARI, Dalmo de Abreu. Elementos da teoria geral do estado. $28^{\text {a }}$ ed. São Paulo: Saraiva, 2009, p. 216.
} 
O principal ponto característico da tradicional noção de separação de poderes constitui-se na noção de que o telos, o fundamento da doutrina, seria assegurar a liberdade do indivíduo. Inegavelmente, o ideal de liberdade não poderia deixar de ser um dos propósitos da teoria do célebre barão francês, proposta como um dos marcos do Iluminismo, não obstante, com a evolução e estudo da teoria, reste cada vez mais claro não ser o seu único sustentáculo.

O fato é que se suprime, com a erupção da lei, o arbítrio do príncipe. E embora o próprio Montesquieu tenha pregado a partir de seus escritos o despotismo esclarecido, não propriamente compatível com a contemporânea noção de soberania popular, a submissão legal por ele proposta diferenciava-se da concepção absolutista de lei anteriormente estruturada a partir da rule of law ${ }^{55}$. Enquanto nesta o soberano devia obediência pura e simples a determinados comandos legais, para Montesquieu a obediência deveria ser apenas uma decorrência lógica do sistema, "pois mais importante que ela era a liberdade de agir em função da permissão da lei ${ }^{56 " \text { " }}$

Essa afirmação, conquanto demonstre a evolução da teoria da separação de poderes de Montesquieu em relação ao rule of law a partir de uma noção iluminista de legalidade, destaca o papel sempre decisivo e central da lei na obra do filósofo, como o instrumento ideológico da luta contra os abusos e arbitrariedades do soberano. Por esse motivo, Nuno Piçarra chega a indicar que a noção de liberdade de que parte Montesquieu em "O Espírito das Leis" nada mais seria que aquela da rule of law, que nega valor à liberdade natural do homem. Seria a liberdade pela lei. Assim, a premissa de que partiria Montesquieu não se diferenciaria qualitativamente da elaboração anterior do

\footnotetext{
${ }^{55}$ A chamada rule of law tem origem na Magna Carta de 1215, a qual instituiu a obrigatoriedade da observância de um processo justo legalmente regulado, quando se tivesse de julgar e punir cidadãos, privando-os de sua liberdade e propriedade. Representou, assim, a proeminência das leis e costumes do país perante a discricionariedade do poder real. Sobre essa definição, v. CANOTILHO, José Joaquim Gomes. Direito Constitucional e Teoria da Constituição. $7^{\mathrm{a}}$ ed. Coimbra: Almedina, 2003, p. 93-94.

${ }^{56}$ WEHLING, Arno. Montesquieu, Barão de. In: BARRETO, Vicente de Paulo. (Org.). Dicionário de Filosofia do Direito. Rio de Janeiro: Unisinos / Renovar, 2006, p. 587.
} 
rule of law. A sua construção de liberdade estaria intimamente ligada à de legalidade ${ }^{57}$.

Piçarra ressalta que somente a partir da elevação da tripartição de funções entre legislativo, executivo e judicial (esta última acrescentada pela teoria de Montesquieu) a obra do Barão introduz determinante variação do tradicional rule of $l a w^{58}$. E, curiosamente, essa leitura jurídica da sua doutrina esteve e ainda se vê frequentemente subestimada e ignorada.

Nem sempre, de fato, viu-se a separação de poderes como separação de funções, sendo ainda comuns lições doutrinárias que resumam o princípio ao controle recíproco entre poderes com vistas a garantir a liberdade dos cidadãos. Poucos foram os que destacaram a importância do conteúdo da divisão de funções entre os 'poderes' de Estado.

Um deles, ainda em tempos mais afastados, foi Miguel Seabra Fagundes, que sempre enfatizou o fato de que tal divisão expressa, antes de tudo, o modo mais adequado de realizar os próprios fins estatais. Fala-se então de função legislativa, administrativa e jurisdicional como as "fases da atividade estatal $^{59, " . ~ J o s e ́ ~ A f o n s o ~ d a ~ S i l v a ~ c o n t r i b u i ~ p a r a ~ a ~ i n t e r l o c u c ̧ a ̃ o: ~}$

"A divisão de poderes fundamenta-se, pois, em dois elementos: (a) especialização funcional, significando que cada órgão é especializado no exercício de uma função; assim às assembleias (Congresso, Câmaras, Parlamento) se atribui a função Legislativa; ao Executivo, a função executiva; ao Judiciário, a função jurisdicional; (b) independência orgânica, significando que, além da especialização funcional, é necessário que cada órgão seja efetivamente independente dos outros, o que postula ausência de meios de subordinação. Trata-se, pois, como se vê, de uma forma de organização jurídica das manifestações do Poder ${ }^{60 "}$ (os grifos são do autor).

\footnotetext{
${ }^{57}$ PIÇARRA, Nuno. A separação dos poderes como doutrina e princípio constitucional: um contributo para o estudo das suas origens e evolução. Coimbra: Coimbra Editora, 1989, p. 90.

${ }_{58}^{5}$ PIÇARRA, Nuno. A separação dos poderes como doutrina e princípio constitucional, p. 91.

${ }^{59}$ FAGUNDES, Miguel Seabra. O Controle dos Atos Administrativos pelo Poder Judiciário. $8^{\text {a }}$ ed., atualizada por Gustavo Binenbojm. Rio de Janeiro: Forense, 2010, p. 3.

${ }^{60}$ SILVA, José Afonso da. Curso de Direito Constitucional Positivo. $33^{\text {a }}$ ed. São Paulo: Malheiros, 2010, p. 109.
} 
Aportes doutrinários e acontecimentos históricos, como a derrocada do Estado Liberal e a já citada crise da lei, impactaram e vêm conformando, aos poucos, o conteúdo da separação de poderes em "duas ideias-força": especialização conjugada com adequação funcional e controle recíproco ${ }^{61}$.

Quanto ao primeiro ponto, atualmente, há uma tendência em se referir à capacidade institucional para designar a aptidão de cada órgão em cumprir eficientemente e de modo profissional as suas missões, diante do quadro da especialização funcional.

\footnotetext{
"Por que a elaboração de leis deve ser atribuição do Legislador? Porque nestas casas, em tese, vigora o pluralismo, a oportunidade para discussão de diferentes pontos de vista e tempo diferenciado. Por que o Executivo deve administrar a máquina pública e implantar políticas públicas? Porque tem equipe com formações especializadas e distintas, tem a possibilidade de planejamento, tem domínio sobre o orçamento, há regras de licitação, entre outros. Assim, a noção de profissionalismo e de capacitação deve ser levada em conta para o exercício das funções do Estado ${ }^{62 \%}$.
}

Observe-se que falar em capacidade institucional não se resume a acentuar as funções indicadas como precípuas ou típicas de cada órgão, muito embora, realmente, elas possam se confundir na maior parte dos casos.

Veja-se que, no cenário atual do judicial review, o fator capacidade institucional tem servido como argumento para promover a autocontenção do juiz na análise de temas essencialmente técnicos, situação em que ele não está qualificado por sua própria formação profissional para decidir em última instância sobre a validade ou invalidade de tal ato ou lei ${ }^{63}$.

Não se nega que as funções de interpretar em caráter último a Constituição e de resolver litígios são atribuídas ao Poder Judiciário, como sua função típica. Mas nem por isso em todo e qualquer caso em que deva interpretar a Constituição, julgando a validade de determinados atos

\footnotetext{
${ }^{61}$ MORGADO, Cíntia. A nova face da separação de poderes - Capacidades institucionais, vinculação dos poderes e constitucionalismo cooperativo, in Revista de Direito da Procuradoria Geral do Estado do Rio de Janeiro. Rio de Janeiro, v. 66, 2011, p. 67.

${ }^{62}$ MORGADO, Cíntia. A nova face da separação de poderes, p. 80.
} 
legislativos ou administrativos, estará o Judiciário habilitado para dar a resposta satisfatória, adequada e correta sobre a questão que lhe foi posta.

De outra ponta, apesar de o exercício de poder normativo, genericamente considerado, pelo Poder Executivo ser uma função atípica sua, em matéria de organização e funcionamento dos seus órgãos é a própria Administração que será mais capaz para indicar suas necessidades e modo de gestão, sendo certamente mais adequado e racional que tal processo esteja alheio à atuação parlamentar, principalmente no cenário do processo legislativo brasileiro em que as emendas parlamentares são amplamente aceitas nos projetos de lei de iniciativa do executivo ${ }^{64}$. A partir dessa visão, o regulamento autônomo não poderia ser taxado com qualquer pecha de inconstitucionalidade por violação à separação de poderes.

O mesmo raciocínio atinente à capacidade institucional será aplicável, por exemplo, ao regramento pela via administrativa de determinadas questões regulatórias. Conforme já exposto, diante de uma sociedade cada vez mais técnica e complexa, nem sempre será o caminho legislativo o meio mais adequado e eficiente para esgotar o tratamento desse tema.

A verdade é que o princípio da separação de poderes sempre compartilhou a possibilidade de edição de atos normativos pelo Executivo, antes mesmo da elevação do princípio da juridicidade. É de se conferir o ensinamento de Augusto Werneck:

"Ora, se a doutrina da separação de Poderes expõe a sede da soberania popular no
Parlamento - na realização da função legislativa, foi urdida principalmente por
MONTESQUIEU e sedimentada por cientistas políticos ou juspublicistas como
STUART MILL, TOCQUEVILLE, HAMILTON, MADISON E JAY, entre outros,
não se poderia deixar de entrever que a corrente teórica responsável pela
sistematização e justificação empírica do ato legislativo trouxe em seu bojo a

${ }^{63}$ cf. BARROSO, Luis Roberto. O controle de constitucionalidade no direito brasileiro, p. 368.

64 "As emendas parlamentares aos projetos de lei de iniciativa privativa do Poder Executivo e Judiciário são admitidas, desde que guardem pertinência temática com o projeto e não importem em aumento de despesas", vide STF, ADI n 2583/RS. Relatora: Min. Carmen Lúcia. Brasília. Data de julgamento: 01/08/2011. 
permissão da própria exceção à regra formulada. Esclarecendo a hipótese tem-se que, na lógica da concepção rígida da tripartição de Poderes, o contraponto da manifestação legiferante legítima e constitucional é justamente o apanágio da edição de atos de conteúdo legal seja no aspecto da generalidade, da coatividade ou da novidade, ou seja, a possibilidade inversa à proposição original. Destarte, a imposição de atos coativos, genéricos e inovadores através do Poder Executivo, a par de ser justo a antítese da utopia liberal, fez parte, de pronto, de sua praxis constitucional $^{65 \%}$.

Observa-se que além de se configurar um verdadeiro mito a ideia histórica de legalidade vinculada à total exclusividade de edição de atos normativos pelo Poder Legislativo, tal possibilidade - a de que se editem leis materiais fora do Parlamento - é cada vez mais exigida dos Estados contemporâneos, por motivos suficientemente claros e justos, já expostos no subcapítulo anterior.

O fato é que, principalmente a partir da noção de juridicidade, há de se falar na existência de verdadeira tendência de dispersão de funções normativas por outros órgãos de Estado, além das casas legislativas. O ponto aqui a ser ressaltado é que essa tendência não gera desequilíbrio na separação de poderes.

Primeiramente, porque, como princípio constitucional, a separação de poderes ou funções é um conceito, assim como muitos outros, cultural e flexível ao contexto institucional e social em que se vê arranjado. Sequer se pode dizer que uma determinada Constituição elenca um modelo rígido e fechado de separação de poderes. No máximo, a Carta Constitucional elege garantias mínimas - o núcleo essencial dos princípios - as quais devem ser protegidas para a própria sobrevivência e higidez do fim que fundamenta o próprio princípio.

O poder normativo do Poder Executivo, conquanto intensificado, ainda se configura uma função atípica, de modo que, preservado o controle recíproco entre os poderes - os checks and balances - e a precípua função legislativa no

\footnotetext{
${ }^{65}$ MARTINS, Augusto Henrique Werneck. Reflexões acerca do poder regulamentar - Propostas à Constituinte, in Revista de Direito da Procuradoria Geral do Estado do Rio de Janeiro. Rio de Janeiro, v. 40, 1988, p. 45-46.
} 
Parlamento, não se pode entender por distorção inconstitucional violadora do princípio da separação de poderes.

E, finalmente, além de serem costumeiros e necessários estes poderes normativos direcionados ao Poder Executivo, tais prerrogativas não devem soar como algo estranho à divisão de funções e nem mesmo à garantia da liberdade que sempre foi parte essencial do conceito de lei formal.

No panorama da divisão de funções, viu-se que, falando em capacidade institucional, o Poder Executivo, diante de determinadas matérias, estará mais apto a regulamentar o seu conteúdo pela própria proximidade institucional que eventualmente disponha. É o caso, por exemplo, da edição de regulamentos autônomos baseados no artigo 84, inciso VI, alínea $a$, da Constituição.

Além disso, a respeito da noção de separação de poderes como o meio ideal para o controle recíproco do poder, especialmente a partir da garantia da legalidade estrita, é bem de dizer que, principalmente nos sistemas de governos presidencialistas, o Poder Executivo goza de ampla margem de legitimidade democrática, apta por si só a assegurar o vasto quadro de prerrogativas normativas a si atribuídas, sem que isso gere um cenário de desequilíbrio entre órgãos de Estado capaz de possibilitar o arbítrio de um poder sobre o outro ou sobre a população.

De tal modo que a previsão de edição de atos normativos pela Administração, especialmente os regulamentos, não frustra a garantia de liberdade dos cidadãos. Preserva-se esta liberdade principalmente a partir de seu caráter positivo, o qual se fundamenta no direito de participação na polis, em última instância assegurando a autonomia da vontade do indivíduo por meio da eleição dos seus governantes administradores. 


\section{CAPÍTULO 3 - NOVAS ABORDAGENS A RESPEITO DO REGULAMENTO DE EXECUÇÃO}

\subsection{Executar fielmente a lei?}

"Em toda palavra de ordem, mesmo de um pai a seu filho, há uma pequena sentença de morte - um veredito, dizia Kafka ${ }^{66, "}$

Os regulamentos de execução são aqueles classicamente elaborados para operar secundum e intra legem. Instrumentalizariam o cumprimento da lei, detalhariam e explicitariam seus comandos, interpretando seus conceitos e dispondo, eventualmente, sobre órgãos e procedimentos necessários para sua aplicação. A eles não seria permitido inovar no ordenamento jurídico, de modo que apenas precisariam o conteúdo de certos conceitos de modo genérico ou imprecisos referidos pela lei, determinando, quando necessário, a maneira de agir da Administração nas suas relações travadas com particulares na oportunidade da execução da norma primária ${ }^{67}$.

Ante tais elucidações, tradicional doutrina não vacila em apontar que, onde não houver liberdade administrativa a ser exercida - caso em que se veja prefigurado na lei o único e possível comportamento da Administração -, não há lugar para regulamento que não seja mera repetição do texto legal ou desdobramento do que nele estiver contido ${ }^{68}$.

Os juízos acima expostos partem de uma concepção clássica do princípio da legalidade e da onipotência da lei. Não obstante a revisão atual, já trabalhada, do fenômeno legal e da noção de legalidade, é preciso

\footnotetext{
${ }^{66}$ DELEUZE, Gilles; GUATTARI, Felix. Mil Platôs: capitalismo e esquizofrenia, vol. 2. São Paulo: Ed. 34, 2011, p. 13.

${ }^{67}$ A definição é encontrada em CLÈVE, Clèmerson Merlin. Atividade Legislativa do Poder Executivo. $3^{\text {a }}$ ed. São Paulo: Revista dos Tribunais, 2011, p. 330.

${ }^{68}$ Cf. BANDEIRA DE MELLO, Celso Antônio. Curso de direito administrativo, p. 348.
} 
problematizar o efeito dessas mudanças especificamente no instituto do regulamento de execução.

Para uma abordagem inicial, merece ser prontamente combatido um fundamental alicerce da interpretação clássica a respeito de tais regulamentos. Trata-se da mencionada tese que pressupõe como hipóteses exclusivas da atuação regulamentar, que não aquela em que se repita literalmente os preceitos expostos na norma fundamentadora, os casos de (i) emprego, voluntário, pela lei, de conceitos juridicamente indeterminados ou (ii) constatação de utilização de termos imprecisos ou genéricos no texto legal, circunstância que seria, supostamente, isolada ${ }^{69}$. Essas situações representariam, enfim, exceções ao modelo de lei como signo fechado, unívoco e limitado. Em tais circunstâncias, não preexistiria um único e possível comportamento da Administração.

A questão que já se põe é: cuidar da textura aberta da linguagem como característica excepcional de textos legais representa um verdadeiro equívoco metodológico. E um equívoco que possibilitou, no Direito Administrativo nacional, a ascensão e manutenção da falsa ideia de que o regulamento executivo não poderia inovar na ordem jurídica, servindo meramente para possibilitar um casto e modesto fiel cumprimento da lei. Sendo assim, adiantese: nunca a lei poderá prever um único e possível comportamento do administrador. O reconhecimento de sua incompletude é, aliás, o motor de mudanças maiores na ciência jurídica, como a elevação do princípio da juridicidade.

No precioso ensinamento de Herbert L. A. Hart, em todos os campos da experiência, e não só do das regras, há um limite, inerente à natureza da

\footnotetext{
${ }^{69}$ Mesmo nesses cenários, de acordo com a doutrina clássica, não se poderia reconhecer eventual inovação na ordem jurídica pela atividade regulamentar, já que o administrador apenas esclareceria conceitos já imbuídos no espírito da lei.
} 
linguagem, quanto à orientação que a linguagem geral pode oferecer ${ }^{70}$. A textura aberta da linguagem, portanto, é "essa característica indelével da linguagem, a consequiência do confronto entre uma linguagem fixa e um mundo desconhecido em constante mudança ${ }^{71 "}$.

Verificando-se inviável a concepção de uma regra tão detalhada que possa resolver por antecipação todas as questões sobre sua aplicação a um caso particular, sem que se envolva uma escolha nova entre alternativas abertas ${ }^{72}$, nunca a lei poderá prever, por exemplo, aquele único e possível comportamento da Administração em todas as circunstâncias particulares que possam envolver o cumprimento da norma. A regulamentação é desejável justamente por reduzir (mas não eliminar) a incerteza sobre o âmbito de regência da lei, oferecendo, de igual modo, maior segurança aos particulares eventualmente subordinados aos ditames legais.

O que se pode falar é que existe uma gradual concretização de preceitos, sendo que mesmo um regulamento executivo, norma secundária, necessariamente conterá disposições mais ou menos abertas. A atividade de interpretação parte de predicados maximamente abstratos, chegando, ao fim do percurso, à aplicação ao caso particular, o que pode ser compreendido não apenas como a prolação de um ato judicial decisório, mas também como a expedição de ato administrativo.

A tarefa do regulamento de execução, diante disso, continua a ser oferecer maior densidade à lei. Porém, isso não significa possibilitar um suposto fiel cumprimento daquilo que já estava contido no âmago da norma primária, mas selecionar e excluir, simultaneamente, significados extraíveis do

\footnotetext{
${ }^{70}$ Cf. HART, Herbert L. A. O Conceito de Direito. Tradução de Armindo Ribeiro Mendes. $6^{\mathrm{a}}$ ed. Lisboa: Fundação Calouste Gulbenkian, 2011, p. 139.

${ }^{71}$ Cf. SCHAUER, F. Playing by the Rules: A Philosophical Examination of Rule-Based DecisionMaking in Law and in Life. Oxford: Oxford University Press, 1991, p. 36. Uma definição igualmente interessante é a que conceitua textura aberta da linguagem como a "possibilidade inafastável que o mais preciso dos termos se torne vago". Em STRUCHINER, Noel. Direito e Linguagem: uma análise da textura aberta da linguagem e sua aplicação ao direito. Rio de Janeiro: Renovar, 2002, p. 63.

${ }^{72}$ Cf. HART, Herbert L. A. O Conceito de Direito, p. 141.
} 
texto legal, que é um campo aberto. A partir da atividade regulamentar, descartam-se, por exemplo, modos de aplicação final da lei que conflitem com a literalidade da nova normatização concretizadora. Isso também é produzir novo direito.

São duas as remissões que podem ser feitas a partir dessas constatações. Primeiramente, à obra de Karl Larenz, para quem o sentido literal da norma representa termo inicial e o limite de qualquer atividade interpretativa. Vedase, por isso, uma densificação regulamentar que contrarie o que foi expressa e taxativamente considerado pela lei, bem como uma execução final do ato que contrarie o direito criado e concretizado pelo regulamento:

"O que está para além do sentido literal linguisticamente possível e é claramente excluído por ele já não pode ser estendido, por via da interpretação, como o significado aqui decisivo deste termo. Diz acertadamente MEIER-HAYOZ que o teor literal tem, por isso, uma dupla missão: é ponto de partida para a indagação judicial do sentido e traça, ao mesmo tempo, os limites da sua actividade interpretativa. Uma interpretação que não se situe já no âmbito do sentido literal possível, já não é interpretação, mas modificação de sentido ${ }^{73}$ ".

A segunda referência, pertinente ao reconhecimento de que o ato regulamentar também é um ato de criação e concretização do direito, dirige-se à obra kelseniana:

"Kelsen considerava a criação do direito, na maioria dos casos, também uma forma de sua aplicação, como consequência imediata do fato de que todo ato criador de Direito deve ser determinado pela ordem jurídica, até por normas de diferentes níveis; para ele 'a questão de saber se um ato é criação ou aplicação de Direito é, na verdade, de todo independente da questão de saber em que grau o órgão atuante é obrigado pela ordem jurídica. Apenas os atos pelos quais não se estabelece norma alguma podem ser mera aplicação de Direito ${ }^{74,}$, .

"Com efeito, se deixarmos de lado os casos-limite - a pressuposição da norma fundamental e a execução do ato coercivo - entre os quais se desenvolve o processo

\footnotetext{
${ }^{73}$ LARENZ, Karl. Metodologia da Ciência do Direito. Tradução de José Lamego. $3^{a}$ edição. Lisboa: Fundação Calouste Gulbenkian, 1997, p. 453-454.

${ }^{74}$ KRELL, Andreas J. Leis de normas gerais, regulamentação do Poder Executivo e cooperação intergovernamental em tempos de Reforma Federativa. Belo Horizonte: Fórum, 2008, p. 69. Os grifos são do autor.
} 
jurídico, todo ato jurídico é simultaneamente aplicação de uma norma superior e produção, regulada por esta norma, de uma norma inferior ${ }^{75}$,".

Assim, a tarefa do regulamento executivo de concretizar em mais um nível o preceito legal possibilita, mais do que viabilizar sua fiel execução e definir o único e exato conteúdo desdobrável do comando jurídico, excluir sentidos que agora com ele não mais irão se compatibilizar. Ao final, repita-se, o último grau de concretização da norma jurídica se dará com a aplicação ao caso particular. A definição da norma individual, ainda nas palavras de Kelsen, definirá o conteúdo possível da lei.

Toda essa construção, que pode ser entendida como um fundamento teórico do novo regulamento de execução, não deixa de se relacionar com lições que já haviam sido propostas por vozes isoladas da doutrina publicista e por esparsas passagens jurisprudenciais.

Assim é que Simone Lahorgue Nunes retrata afirmação contundente de Rui Barbosa, também recuperada por Caio Tácito ${ }^{76}$, ainda na primeira década do século passado:

"a noção elementar a todas as Constituições, de que os regulamentos se formulam para executar unicamente as leis ficou reduzido a uma ficção" (...) "do regular ao legislar, do legislar ao regular nem sempre são claras as raias. Entre as duas competências medeia uma zona de fronteira indecisa, mista, por uma ventura comum, em que ora as leis regulamentam, ora os regulamentos legislam ${ }^{77, "}$

André Rodrigues Cyrino consigna muito claramente que criação $e$ execução do direito não se apresentam em plano estanques ${ }^{78}$. Não há, portanto, uma divisão asséptica e evidente entre legislar, regulamentar e

\footnotetext{
${ }^{75}$ KELSEN, Hans. Teoria Pura do Direito. Tradução de João Baptista Machado. 6a ed. São Paulo: Martins Fontes, 1998, p. 164.

${ }^{76}$ TÁCITO, Caio. Parecer sobre o poder regulamentar do Conselho Monetário Nacional e da Comissão de Valores Mobiliários, in Revista da CVM. Rio de Janeiro, v. 4, n. 12, 1986, p. $28-29$.

${ }^{77}$ NUNES, Simone Lahorgue. Os Fundamentos e os Limites do Poder Regulamentar no Âmbito do Mercado Financeiro. Rio de Janeiro: Renovar, 2000, p. 121-122.

${ }^{78}$ CYRINO, André Rodrigues. O poder regulamentar autônomo do Presidente da República, p. 86.
} 
mesmo aplicar o direito ao caso concreto, sendo todos esses planos do processo de produção jurídica.

Gustavo Binenbojm indica, do mesmo modo, que a ideia de fiel cumprimento "deve ser lida cum grano salis, eis que não se pode reduzir a atividade administrativa regulamentar a uma simples aplicação mecânica da lei" e que a noção de regulamento de execução "não pode ser circunscrita a uma atividade basicamente repetidora da lei, ou um mero elemento de sua execução, como um procedimento de sua aplicação". E remata concluindo que quase sempre haverá espaço para a atividade criativa do poder regulamentar de execução ${ }^{79}$.

Ainda que timidamente, o Supremo Tribunal Federal, na pena do Ministro Celso de Mello, já chegou a questionar concepção clássica do regulamento de execução como mero repetidor ou mecânico executor dos preceitos legais:

"É preciso ter presente que, não obstante a função regulamentar efetivamente sofra os condicionamentos normativos impostos, de modo imediato, pela lei, o Poder Executivo, ao desempenhar concretamente a sua função regulamentar, não se reduz à condição de mero órgão de reprodução do conteúdo material do ato legislativo a que se vincula. Há que se reconhecer ao Poder Executivo, embora limitadamente, um círculo de livre regramento da matéria, em cujo âmbito seja-lhe atribuído um resíduo de atuação jurídica" ${ }^{80}$.

Retomando doutrina de Alexandre Santos de Aragão ${ }^{81}$, novamente André Rodrigues Cyrino relaciona três modelos em que a atuação regulamentar pode se inserir, de acordo com o nível prévio de consistência legal. Confira-se:

\footnotetext{
${ }^{79}$ BINENBOJM, Gustavo. Uma Teoria do Direito Administrativo, p. 156-157.

${ }^{80}$ STF, ADI $\mathrm{n}^{\circ}$ 561-8/DF, Relator: Min. CELSO DE MELLO. Brasília. Data de Julgamento: 23/08/1995.

${ }^{81}$ ARAGÃO, Alexandre Santos de. Princípio da Legalidade e Poder Regulamentar no Estado Contemporâneo, in Revista de Direito da Procuradoria Geral do Estado do Rio de Janeiro. Rio de Janeiro, v. 53, 2001.
} 
“(i) as leis de densidade normativa exaustiva, impostas por uma reserva absoluta de lei, deixam o menor espaço possível ao regulamento (como por exemplo a instituição de tributos, crimes e penas, artigo $5^{\circ}$, XXXIX; 150, I, da Constituição), mas reconhecendo que a plena exaustão capaz de excluir qualquer subjetividade do aplicador é irrealizável na prática; (ii) as leis de grande densidade normativa, não sujeitas a uma reserva absoluta de lei e nas quais haveria ampla aplicação dos regulamentos de execução conforme a doutrina tradicional os concebe, de detalhamento das disposições do legislador, que, na verdade, não é mera repetição da letra da lei, mas "criação", "mesmo que moderada", de alguns aspectos dos elementos da prestação de obrigação; e (iii) leis de baixa densidade normativa, categoria em que se classificam as "leis quadro (lois-cadre) ou standartizadas, próprias das matérias de grande complexidade técnica e suscetíveis de constantes mudanças ${ }^{82}$,.

Ao fim de tudo isso, o que se percebe é que se vive em um momento propício para a superação da noção de regulamento executivo como mero complemento à lei. É o momento de ascensão da juridicidade. Reconhece-se, aos poucos, a fundamental importância e o papel chave do regulamento na construção do ordenamento jurídico. Isso pode ser visto, em grande parte, por meio da elaboração das tais leis de baixa densidade normativa, em que se defere ao administrador e a entes independentes a ampla e precípua normatização de certos temas.

Se é bem verdade que, por um lado, o regulamento nunca deixou de produzir direito, já que inovar na ordem jurídica é atributo inescapável de qualquer texto normativo, atualmente, mais do que nunca, é possível e desejável admitir tal circunstância, rechaçando a figura do fiel executor da lei. Não mais se deve reconhecer no administrador uma figura perversa, sempre pronta a violar direitos de particulares e instaurar o arbítrio.

De todo modo, para que se enterre de vez essa suposição, é preciso, por fim, inserir (i) a participação democrática na elaboração regulamentar e (ii) um eficaz controle repressivo de suas disposições flagrantemente contrárias à lei ou simplesmente inconstitucionais, garantindo accountability.

Enquanto o último ponto será tratado pormenorizadamente no próximo subcapítulo, quanto ao primeiro deve-se concisamente dizer que urge a criação

\footnotetext{
${ }^{82}$ CYRINO, André Rodrigues. O poder regulamentar autônomo do Presidente da República, p. 90-91.
} 
de mecanismos participativos no âmbito da Administração central. Enquanto o reconhecimento do poder normativo das agências reguladoras veio acompanhado, através da própria legislação de criação das agências, de instrumentos propiciadores de efetivo diálogo na atuação desses entes, ainda são comuns os decretos regulamentares simbólica e exclusivamente baixados no interior do gabinete do Executivo, não poucas vezes pegando de surpresa atores envolvidos na temática regulamentada.

Não se ignora que o governante eleito esteja, a princípio, distante dos questionamentos relacionados ao déficit democrático sofrido por autoridades administrativas independentes. Entretanto, com isso não deve se admitir que a sua atividade normativa possa prescindir de algum diálogo direto com a sociedade. Especialmente porque, como já exaustivamente abordado, seu grau de criação do direito aumenta exponencialmente na sociedade contemporânea.

É preciso assegurar algo como uma legitimação pelo procedimento ${ }^{83}$, devendo a estrutura do Executivo realizar, de maneira rotineira, audiências e consultas públicas. Reuniões com representantes dos setores sociais podem estimular, da mesma forma, uma elaboração negocial de normas jurídicas, privilegiando também as diretrizes mais modernas de consensualidade no Direito Administrativo.

\subsection{Controle dos atos regulamentares. A defesa do controle jurisdicional abstrato de constitucionalidade dos regulamentos de execução}

Diante das proposições lançadas, que apontam para um crescente prestígio da competência regulamentar, deve-se chegar a uma conclusão inafastável: é imprescindível que os mecanismos controle de tais atos estejam

\footnotetext{
${ }^{83}$ Sobre o tópico, ainda que circunscrito à prática das agências reguladoras, confira-se BINENBOJM, Gustavo. Uma Teoria do Direito Administrativo, p. 294-305.
} 
reforçados, sendo, também, sempre que possível, ampliados. Afinal, grandes poderes trazem grandes responsabilidades.

É sabido que uma das principais tendências no direito público moderno é a maior ênfase na fiscalização e controle das atividades de Estado ${ }^{84}$. Essa perspectiva, deve-se dizer, tem como um dos grandes marcos na doutrina jurídica brasileira a obra clássica de Miguel Seabra Fagundes, $O$ Controle dos Atos Administrativos pelo Poder Judiciário. Na atuação da Administração Pública, por exemplo, cresce o foco na investigação dos atributos tanto do controle interno, caso de questões envolvendo o princípio da autotutela, como também do controle externo, por meio da atividade de órgãos constitucionais independentes, como os Tribunais de Contas e Ministério Público, e também do Poder Judiciário.

Em relação à apreciação da produção legislativa, o judicial review já é tema recorrente. O estágio atual da jurisdição constitucional no Brasil e o relativo protagonismo dos Tribunais são questões minuciosamente abordadas em inúmeros trabalhos doutrinários. Tamanha é a representatividade que tomou a temática do controle, fiscalização e correição de atos administrativos e legislativos, que já é possível constatar uma reação nas Casas Legislativas e nas Chefias do Executivo contra a exacerbada interferência judicial em matérias que deveriam ter como grandes instâncias decisórias os órgãos democraticamente eleitos, como é o caso do arranjo de políticas públicas. Falase, então, em judicial restraint (autocontenção judicial), para a proteção das capacidades institucionais de cada órgão.

Feita essa breve introdução do panorama do controle judicial de atos legislativos e administrativos no Brasil e, inobstante a profundidade teórica que pode tomar o debate a respeito dos limites da atuação dos órgãos de controle, vê-se, desde já, que, no caso dos regulamentos de execução, há um instrumento

\footnotetext{
${ }^{84}$ Faça-se referência ao belo excurso sobre o tema encontrado em de ENTERRÍA, Eduardo García de. Democracia, jueces y control de la Administración. $3^{\mathrm{a}}$ edição. Madri: Civitas, 1997, p. 112-121.
} 
típico e constitucionalmente assegurado para verificar possíveis excessos em sua edição. Trata-se do controle político-legislativo, baseado no artigo 49, V, da Constituição, que prevê a competência do Congresso Nacional para sustar os atos normativos do Executivo que exorbitem o poder regulamentar.

A referida norma não faz nada mais nada menos que traduzir, em uma importância prerrogativa congressual, a supremacia da lei face ao regulamento de execução. A grande questão que se pôs, a partir de então, foi indagar se o juízo a ser feito pelo legislador-congressista seria de discricionariedade ou de legalidade. André Rodrigues Cyrino aponta que, considerado o impacto que poderia advir na doutrina da separação de poderes o entendimento que o legislador poderia substituir a discricionariedade do Administrador pela sua própria, a doutrina majoritária brasileira acabou por apontar que o controle exercido a partir do artigo $49, \mathrm{~V}$, seria de legalidade ${ }^{85}$.

Adotando exatamente essa lógica foi que o Supremo Tribunal Federal, nos autos da ADI $\mathrm{n}^{\circ} 748 / \mathrm{RS}^{86}$ e da ADI $\mathrm{n}^{\circ} 1553 / \mathrm{DF}^{87}$, entendeu pela viabilidade do ajuizamento de ação direta de inconstitucionalidade em face de decreto legislativo que suste ato normativo regulamentar do Poder Executivo. Nas palavras dos Ministros relatores, a generalidade e abstração dos atos impugnados permitiriam o exame final de compatibilidade entre a atuação congressual e a Constituição, em um juízo amplo de legalidade. A fiscalização estrita dos pressupostos legitimadores do ato de sustação permitiria, igualmente, preservar a integridade do princípio da separação de poderes.

Tais precedentes, a propósito, prenunciam o segundo tipo de controle do regulamento de execução. Trata-se do controle jurisdicional. Dentro dessa espécie, além da verificação de legalidade, admite-se amplamente a análise de constitucionalidade de disposições regulamentares pela via concreta e difusa.

\footnotetext{
${ }^{85}$ Cf. CYRINO, André Rodrigues. O poder regulamentar autônomo do Presidente da República, p. 180 .

${ }^{86}$ STF, ADI no 748/RS. Relator: Min CELSO DE MELLO. Brasília. Data de julgamento: 01/07/1992.

${ }^{87}$ STF, ADI n ${ }^{\circ}$ 1553/DF. Relator: Min MARCO AURÉLIO. Brasília. Data de julgamento: 12/05/2004.
} 
Assim como ocorre com outros exemplos de atos normativos, o controle incidenter tantum do regulamento de execução não sofre qualquer tipo de limitação senão aqueles próprios do controle concreto/difuso, referentes à extensão dos seus efeitos - nunca será um pronunciamento erga omnes de inconstitucionalidade, já que fundamento presente apenas na razão de decidir da sentença ou acórdão.

A grande pedra de toque do tema do controle jurisdicional do regulamento de execução está na possibilidade de controle abstrato de constitucionalidade dos regulamentos de execução por via de ação direta. Ação direta aqui entendida como a própria Ação Direta de Inconstitucionalidade (ADI), regulada pela Lei Federal no 9.868/1999.

A jurisprudência do Supremo Tribunal Federal se posiciona de longa data pelo apriorístico não cabimento de ADI para questionamento de inconstitucionalidade de atos regulamentares ${ }^{88}$. Em geral, argumenta-se que, por se subordinarem a uma lei prévia, não se estabeleceria um confronto direto entre eles e a Constituição ${ }^{89}$. Resumindo, a hipótese seria de desconformidade do regulamento com a lei que lhe cabia regulamentar, o que caracterizaria mera ilegalidade, ou de inconstitucionalidade da própria lei, não sendo caso de impugnação do ato secundário em si $^{90}$.

\footnotetext{
${ }^{88}$ Por todas as decisões, veja-se a proferida na ADI 4218/DF, assim ementada: "AGRAVO REGIMENTAL. AÇÃO DIRETA DE INCONSTITUCIONALIDADE. DIREITOS CONSTITUCIONAL, ADMINISTRATIVO E AMBIENTAL. PODER REGULAMENTAR (ART. 84, IV, DA CONSTITUIÇÃO). DECRETO QUE ESTABELECE PARÂMETROS E CRITÉRIOS PARA O LICENCIAMENTO AMBIENTAL DE EMPREENDIMENTOS POTENCIALMENTE NOCIVOS AO PATRIMÔNIO ESPELEOLÓGICO BRASILEIRO. FARTA DISCIPLINA LEGAL. EVENTUAL OFENSA CONSTITUCIONAL MERAMENTE REFLEXA OU INDIRETA. INAPLICABILIDADE AO CASO DO ART. 225, § $1^{\circ}$, III, DA CARTA MAGNA. EXIGÊNCIA DE LEI APENAS PARA A ALTERAÇÃO E SUPRESSÃO DE ESPAÇOS TERRITORIAIS ESPECIALMENTE PROTEGIDOS, SITUAÇÃO DIVERSA DO CASO SUB JUDICE. AGRAVO CONHECIDO E DESPROVIDO" (STF, ADI-AgR 4218/DF. Brasília. Relator: Min. LUIZ FUX. Data de Julgamento: 13/12/2012).

${ }^{89}$ Repita-se, aqui tratando do regulamento de execução. Admite a Corte, inversamente, a análise de regulamentos autônomos, por se configurarem como atos normativos primários, fundados diretamente do texto constitucional.

${ }^{90}$ Cf. BARROSO, Luis Roberto. O controle de constitucionalidade no direito brasileiro, p. 203.
} 
As mesmas razões, de acordo com o Tribunal, impossibilitariam até mesmo o cabimento de ADPF, com a sua singular característica da subsidiariedade, prevista pelo artigo $4^{\circ}, \S 1^{\circ}$, da Lei Federal $n^{\circ}$ 9.882/1999 ${ }^{91}$.

Entretanto, há fortes argumentos passíveis de serem manuseados para que se conteste tal posicionamento do Supremo Tribunal Federal. Em primeiro lugar, e versando sobre um raciocínio lógico, não parece haver grande coerência em se admitir o controle jurisdicional do decreto legislativo de sustação do ato regulamentar e, por outro lado, impossibilitar o ajuizamento imediato de ADI contra o regulamento de execução.

Ora, ambos os argumentos utilizados na ADI $n^{\circ} 748 / \mathrm{RS}$ e na ADI $n^{\circ}$ 1553/DF não contrariam, em tese, e até reforçariam a necessidade de controle jurisdicional abstrato dos regulamentos. Assim é que, como fartamente demonstrado, os regulamentos se configuram como leis materiais, também obtendo generalidade e abstração. Além disso, a necessária verificação de respeito ao princípio da separação de poderes, ao permitir ao STF fiscalizar a utilização da prerrogativa inserta no artigo $49, \mathrm{~V}$, da Constituição não é uma hipótese isolada de possível afronta a princípios constitucionais. A elaboração de um regulamento em desconformidade com o texto constitucional pode se traduzir em ataque ainda mais grosseiro à Constituição, tanto no que diz respeito à exorbitação do poder regulamentar (hipótese não menos nociva à separação de poderes) quanto a outras infinitas e possíveis inconstitucionalidades desvairadas.

É claro que há um argumento simbólico - além de outro, pragmático ${ }^{92}$ na postura do Supremo Tribunal Federal. A relevância dada ao sistema de controle de legalidade, por meio da noção de inconstitucionalidade indireta,

\footnotetext{
91 Vide STF, ADPF no 169/DF, Relator: Min. RICARDO LEWANDOWSKI. Brasília. Data de Julgamento: 08/05/2009.

92 Qual seja, o medo de uma enxurrada de ações em um Tribunal já quase asfixiado pela excessiva carga de trabalho. Esse é um argumento atécnico e pequeno, do qual não se deveria utilizar uma Suprema Corte, até porque o tratamento do problema passa por questões mais complexas do que a simples utilização de jurisprudência defensiva.
} 
oferece certo prestígio à autoridade da lei e à atuação do legislador, que inclusive teria algo como uma prioridade institucional para corrigir os excessos regulamentares por meio da utilização da prerrogativa do artigo $49, \mathrm{~V}$.

Esses argumentos também merecem ser enfrentados. Inicialmente, não parece ser condizente com o modelo acima proposto admitir, isoladamente, o controle jurisdicional abstrato do decreto legislativo de sustação do ato regulamentar. Se a intenção original é oferecer relevo à iniciativa do legislador de aferir possíveis irregularidades na edificação do regulamento, o raciocínio lógico consequente seria o não conhecimento de tal tipo de ação. Mas, como visto, o Supremo Tribunal Federal admite o referido controle.

E isso só ocorre porque reconhece a própria Corte a necessidade, de uma maneira ou de outra, de oferecer a última palavra sobre a interpretação e validade de atos reputados como inconstitucionais. E o ponto é esse: qual é o embasamento teórico que justifica o não conhecimento de ações diretas contra regulamentos de execução, já que se configuram genericamente como atos normativos, em congruência com o artigo 102, I, $a$, da Constituição?

Na lição de Vanessa Vieira de Mello, a qual é de se corroborar, a ofensa do ato regulamentar à Carta Magna "não precisa necessariamente ser reflexa. E mesmo que seja indireta, acaba por destoar a Constituição, fato suficiente para ensejar o controle de constitucionalidade" ${ }^{\text {"93. }}$.

O mais curioso, entretanto, é que o Supremo Tribunal não raramente admite conhecer de ações impugnativas de dispositivos regulamentares, supostamente quando estes transbordem, de maneira inequívoca, os limites da

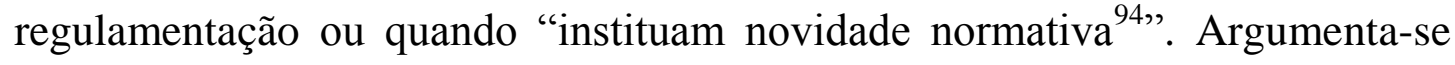
que tais atos normativos acabam não detendo mero caráter regulamentar, mas sim autônomo, o que geraria violação ao princípio da legalidade.

\footnotetext{
${ }^{93}$ MELLO, Vanessa Vieira de. Regime Jurídico da Competência Regulamentar. São Paulo: Dialética, 2001. p. 117.

${ }^{94}$ Vide STF, ADI $n^{\circ}$ 3664/RJ, Relator: Min. CEZAR PELUSO. Brasília. Data de Julgamento: $01 / 06 / 2011$.
} 
Mesmo ignorando a utilização da expressão novidade normativa, já que de qualquer ato normativo se espera algum grau de inovação, tal argumento, ao apartar apenas algumas situações concretas, sofre de uma contradição transparente: ultrapassar, inequivocamente ou não, o limite da regulamentação, violar o princípio da legalidade e exorbitar, em geral, o poder regulamentar não tratam de questões diferentes: referem-se a um juízo de legalidade ampla. E é um juízo que não deixa de ser de constitucionalidade, já que a legalidade, em várias de suas facetas, é princípio constitucional.

Mas não é só: por que um regulamento que institua benefícios fiscais não previstos em lei ${ }^{95}$ ou crie cargos públicos ${ }^{96}$ pode ser mais inconstitucional que outro que, ainda que limitado a um etéreo espaço de regulamentação, acabe agredindo, por exemplo, um direito fundamental? A noção de inconstitucionalidade indireta permite a manutenção no ordenamento jurídico de tal dispositivo? Ainda: tal dispositivo, ao padecer de inconstitucionalidade em descompasso com a lei que lhe fundamenta, também não acaba, ao fim e ao cabo, transbordando o limite regulamentar e ferindo o princípio da legalidade?

Todas essas são questões em aberto, que precisam ser tratadas de maneira técnica e criteriosa, características não observadas na atual incoerência metodológica do Supremo Tribunal Federal na abordagem do tema ${ }^{97}$.

\footnotetext{
${ }^{95}$ Como tratado na ADI $n^{\circ} 3664 / \mathrm{RJ}$, já apontada.

${ }^{96}$ Cf. STF, ADI $n^{\circ}$ 3232/TO, Relator: Min. CEZAR PELUSO. Brasília. Data de Julgamento: $14 / 08 / 2008$.

97 Por questão de retidão, é justo mencionar que o Ministro Gilmar Mendes, ainda que doutrinariamente e com argumentos restritos, contesta algumas das bases da postura tradicional da Corte. Transcreva-se sua lição: "Independentemente da aceitação da tese sobre a inconstitucionalidade indireta, deve-se reconhecer que a orientação segundo a qual o confronto lei/regulamento configura questão legal, que não pode ser tratada no controle abstrato de normas, não há de ser aceita sem ressalvas" (...) "Disso resulta diretamente, pelo menos no que concerne aos direitos individuais, que a ilegalidade de um regulamento equivale a uma inconstitucionalidade, porque a legalidade das normas secundárias expressa princípio do direito constitucional objetivo" (...) "Entendimento contrário levaria à uma completa ruptura com a necessária vinculação da administração à Constituição, uma vez que ela poderia editar qualquer ato regulamentar, ainda que em contradição com os direitos individuais, sem observância do princípio da reserva legal. Nesse caso, tal como já ressaltado por Papier, a legalidade da restrição configura condição de sua constitucionalidade. A contrariedade à lei representa sempre um caso de ofensa a direito individual”. Em MENDES, Gilmar Ferreira. Jurisdição Constitucional: o Controle Abstrato de Normas no Brasil e na Alemanha. 5a edição. São Paulo: Saraiva, 2005.
} 


\section{CAPÍTULO 4 - BREVES APONTAMENTOS SOBRE O REGULAMENTO AUTÔNOMO NO DIREITO BRASILEIRO}

\subsection{Definição, limites e possibilidades}

O regulamento autônomo, com as feições que hoje se discute, foi introduzido no ordenamento jurídico brasileiro pela Emenda Constitucional número 32, que veio a alterar a redação original do artigo 84, inciso VI, alínea $a$ da Constituição Federal. Como se realça de sua interpretação literal, cabe a edição de decreto, agora independente de lei, para dispor sobre organização e funcionamento da administração, quando não implicar aumento de despesa nem criação ou extinção de órgãos público.

Diferentemente do regulamento de execução, a espécie ora tratada decorre diretamente do texto constitucional, não se encontrando cingida a qualquer lei. Embora hoje reste quase incontroversa a existência do regulamento autônomo, reconhecido e debatido em inúmeras obras doutrinárias e largamente observado na prática administrativa, forte doutrina tradicional ainda o ignora. Para Celso Antônio Bandeira de Mello, a nova redação do artigo 84 supracitado não altera em nada a relação da Administração com a legalidade nem lhe confere qualquer liberdade extralegal. $\mathrm{O}$ autor indica que a previsão constitucional apenas faculta "que o Executivo proceda no interior dos esquemas já legalmente traçados de maneira genérica", sendo decorrente do poder hierárquico qualquer manifestação daí derivada sobre o funcionamento da Administração ${ }^{98}$.

\footnotetext{
${ }^{98}$ BANDEIRA DE MELLO, Celso Antônio. Curso de direito administrativo, p. 103-104, nota de rodapé número 9. Os grifos são do próprio autor.
} 
Em verdade, a discussão sobre a existência ou não do regulamento autônomo sempre foi muito forte e muito cara aos publicistas. Alguns eram os que já defendiam uma zona regulamentar reservada mesmo anteriormente à EC 32/01, embasando-se em grande parte na própria manifestação de poder hierárquico (porém independente de lei, diferentemente do que defendido por Bandeira de Mello $)^{99}$ e em um suposto poder discricionário ${ }^{100}$.

Por outro lado, é necessário assumir que, sem a expressa autorização do novo artigo 84, inciso VI, $a$ da Constituição, não era das tarefas mais fáceis defender a existência do regulamento autônomo no Brasil, especialmente diante da falta de parâmetros claros a permitir o seu manejo, problema, diga-se, não totalmente solucionado pela alteração constitucional. Se houve uma grande mudança de entendimento doutrinário e jurisprudencial após a EC 32/01, admitindo-se agora a existência do regulamento autônomo, as novas tendências e divergências, na lição de André Rodrigues Cyrino, passam por abordar questões relativas aos limites e possíveis controles de tais atos ${ }^{101}$.

Assim, diante da consagração do instituto, doutrina e administradores começam a se enveredar pelo conteúdo do novo dispositivo constitucional. Qual é o território relativo à organização e funcionamento da administração em que se possibilita a utilização de decreto autônomo? Em primeiro lugar, dessa indagação deve se extrair uma conclusão relativamente óbvia, apesar de pouco trabalhada pelos poucos que rejeitam a existência do regulamento autônomo:

\footnotetext{
${ }^{99}$ Leciona Paulo Otero, ainda que não versando logicamente sobre a realidade brasileira, que "não se pode ignorar a existência de regulamentos fundados num poder de auto-organização interna que existe no seio de cada estrutura decisória administrativa e que não depende de expressa previsão legal: tal como cada órgão titular de poderes intra-administrativos hierárquicos de intervenção pode emanar regulamentos internos, também cada órgão colegial goza sempre de uma competência própria para elaborar o respectivo regimento. Em qualquer das hipóteses, deparamos com o exercício de uma competência regulamentar que não carece de uma habilitação legislativa escrita: os regulamentos fundados no poder de auto-organização alicerçam-se num princípio geral de Direito não escrito". Em OTERO, Paulo. Legalidade e Administração Pública, p. 456.

${ }^{100}$ Cite-se, também, Sérgio Ferraz, resgatado em BINENBOJM, Gustavo. Uma Teoria do Direito Administrativo, p. 168, nota de rodapé número 372.

${ }^{101}$ CYRINO, André Rodrigues. O poder regulamentar autônomo do Presidente da República, p. 142.
} 
não são frágeis e nem brandos os limites à atuação do administrador. A existência do regulamento autônomo não deve significar o oferecimento de uma liberdade qualquer ao administrador. Em verdade, não há grande liberdade normativa na edição de regulamentos autônomos.

Para se depreender o alcance de sua atuação, não há outra saída senão apurar qual foi a inovação introduzida pela Emenda Constitucional número 32. Anteriormente à sua edição, o artigo 84 do texto original da Constituição de 88 previa competir ao Presidente da República "dispor sobre a organização e o funcionamento da administração federal, na forma da lei”. A primeira e principal alteração promovida pela Emenda foi, portanto, retirar a expressão "na forma da lei". Porém, a indicação do surgimento de uma espécie regulamentar autônoma não adveio apenas dessa mudança.

Foi alterado, por meio da mesma Emenda Constitucional, o inciso XI do artigo 48 da Constituição, retirando as expressões "estruturação e atribuições de Ministérios e órgãos" daquelas matérias a serem especialmente regulamentadas por lei. Além disso, e confirmando a intenção da alteração constitucional, a mesma expressão foi retirada do artigo $61, \S 1^{\circ}$, II, $e$, que cuida dos assuntos de iniciativa privativa do Chefe do Executivo. A conclusão a se chegar, portanto, é que a regulamentação de tais matérias, "estruturação e atribuição" (originalmente citada nos artigos 48 , XI e $61, \S 1^{\circ}$, II, $e$ ), inserindose no conceito de "organização e funcionamento" (artigo 84, inciso VI, $a$ ), seriam a partir de então atribuições normativas autônomas do Chefe do Executivo, encontrando-se fora do processo legislativo ${ }^{102}$.

A intenção aparente do constituinte derivado reformador foi, em uma visão geral, delegar as atividades que dialoguem com o arquétipo de organização da Administração (donde é possível extrair ações como as citadas no texto constitucional - estruturar, atribuir - e mais algumas outras, como

\footnotetext{
${ }^{102}$ Cf. CYRINO, André Rodrigues. O poder regulamentar autônomo do Presidente da República, p. 143-144.
} 
arranjar, arquitetar, coordenar) ao domínio do regulamento. Um domínio alheio ao processo legislativo, o que não significa, entretanto, afrontar os princípios de legalidade e separação de poderes, em especial diante da interpretação mais atual desses valores, já analisada.

Se a boa notícia é que parece incontestável a existência dessa zona regulamentar autônoma, a má também já foi prenunciada: a tarefa de delimitar o espaço do que será organizar, estruturar, atribuir não é simples, particularmente no confronto com situações concretas. E, talvez, pensando exatamente nessas situações fáticas é que será possível extrair parâmetros, critérios para que se forme uma base sólida para a consolidação do conteúdo do regulamento autônomo no Brasil.

Dessa maneira, no que se poderia identificar como uma zona de certeza positiva, inegável tema de edição de regulamento autônomo, estaria a hipótese de alteração da vinculação ou subordinação de determinado órgão administrativo a outro órgão ou estrutura superior da Administração, caso em que o intuito de (re)organização administrativa se mostraria evidente. O mesmo se poderia dizer da definição da forma de composição de certos conselhos administrativos, instituídos como forma de coordenação entre órgãos isolados.

É de se observar, por outro lado, que estará vedada a edição de decreto que não se limite a organizar a Administração, mas que, por exemplo, preveja sanções não criadas anteriormente em lei formal ou institua atividade ou programa que implique aumento de despesa pela Administração - esta última conjectura expressamente rechaçada pelo texto constitucional.

Observadas hipóteses inequívocas de viabilidade e inviabilidade da utilização da prerrogativa contida no artigo 84, VI, $a$, é possível detectar uma zona cinzenta em situações menos claras, não facilmente classificáveis como matéria de organização e funcionamento administrativos. Como já exposto, as atividades de estruturação e atribuição, diante das mudanças elencadas pela EC 
32/01, parecem estar contidas em organização e funcionamento. Pergunta-se: seria possível estabelecer, por decreto, atribuições que possam extrapolar o âmbito interno da Administração e afetar diretamente interesses de terceiros?

Em determinados casos, fixar atribuições representa meramente uma readequação administrativa, visando à melhor eficiência interna ${ }^{103}$. Assim, seria regulamentável por decreto não somente a transferência de certas atribuições de um órgão para o outro, mas a própria criação de novo órgão com atribuição específica, em uma interpretação criativa do artigo 84 da Constituição. Nessa última situação, respeitadas duas condições: primeiramente, que a eficácia dessa atribuição e a atuação do órgão sejam exclusivamente internas à Administração e que, aproveitando cargos já existentes, não represente a constituição de uma nova estrutura no seio administrativo $^{104}$ (como Ministérios ou Secretarias, órgãos autônomos, na tradicional classificação doutrinária).

Contrariamente, se o estabelecimento de atribuições represente a indicação de autoridade competente para aplicação de punição a particular, ainda que a própria sanção já esteja prevista em lei, seria questionável a sua instituição ou alteração por decreto autonomamente elaborado. Esse exemplo será retomado à frente. Nesse caso, diga-se, o modelo ideal de regulamentação seria uma densa normatização a ser realizada pela própria lei que preveja a sanção, como forma de respeito ao princípio da reserva legal.

De todo o exposto, o que se percebe é que está limitada a edição de regulamentos autônomos aos assuntos estritamente internos à Administração, dentro do que se possa aferir como norma de organização e funcionamento.

\footnotetext{
${ }^{103}$ André Rodrigues Cyrino, nessa situação, defende a preservação da reserva de administração e faz referência ao Projeto de Lei de Conversão número 1 de 2003 (Medida Provisória número 79/02 "Estatuto do Torcedor"), em que o Chefe do Executivo Federal vetou dispositivos que estabeleciam atribuições ao Ministério do Esporte, por serem estas ínsitas à organização e funcionamento da Administração, de maneira que deveriam ser objeto de decreto. Cf. CYRINO, André Rodrigues. $O$ poder regulamentar autônomo do Presidente da República, p. 152.

${ }^{104}$ Cf. CYRINO, André Rodrigues. O poder regulamentar autônomo do Presidente da República, p. 155.
} 
Por esse motivo é que se falou que não existe, verdadeiramente, grande liberdade do administrador. Resta inviável e inconstitucional a regulamentação de assunto que, a pretexto de se afirmar como matéria interna, acabe atingindo situações externas de particulares, em especial quando se vislumbrar afronta a temas protegidos por reserva de lei. Algumas dessas situações serão abordadas no próximo subcapítulo.

De resto, nas matérias de organização e funcionamento, vige uma reserva de administração, que há de se entender alheia à da lei ${ }^{105}$.

É possível, ao fim, estabelecer um traço de comparação entre o regulamento autônomo, do modo como inserido no ordenamento constitucional e jurídico brasileiro, com o chamado regulamento administrativo. A figura do regulamento administrativo remete à doutrina e prática alemã clássica de diferenciar regulamentos jurídicos e regulamentos administrativos. Enquanto aqueles teriam uma eficácia externa ao seio da Administração, sendo voltados tipicamente para regular atividades e comportamentos de terceiros, estes últimos seriam editados em assuntos de interesse interno da prática administrativa, como a sua organização, e também na estruturação das relações de indivíduos sob a submissão direta do Estado (relações especiais de sujeição).

\footnotetext{
${ }^{105}$ Há alguma polêmica quanto ao tema. Além da grande doutrina que simplesmente rejeita a existência de regulamentos autônomos, há quem admita a sua existência, porém veja intacta a universalidade temática da lei, de modo que haveria a possibilidade de edição de regulamentos para tratar das hipóteses do artigo 84, VI, $a$, porém subsistindo o princípio da preferência da lei. Ou seja, em caso de superveniência de lei, esta prevaleceria sobre qualquer disposição regulamentar. A defender esta abordagem, veja-se BINENBOJM, Gustavo. Uma Teoria do Direito Administrativo, p. 167-170. Conquanto muito bem fundamentada, parece que essa doutrina, por se situar "no meio do caminho", não explora o potencial de utilização dos regulamentos autônomos. Representa admitir que um decreto regulamentar nunca poderá abordar livremente as matérias elencadas no próprio artigo 84, VI, $a$ : isto é, se uma determinada lei trata da organização de certo órgão público, qualquer alteração nesta organização somente poderia ocorrer, a princípio, por nova lei. O regulamento autônomo, assim, já estaria fadado ao fracasso, impondo-se uma castração que retiraria o próprio significado de sua existência, de forma que mais adequado seria negá-lo. Por esses e outros motivos, é de se crer que a melhor posição há ser tomada após a edição da EC 32/01 é a de defesa de uma zona reservada de administração, território de ampla e total normatização por via de regulamento. Em defesa dessa interpretação, confira-se CYRINO, André Rodrigues. O poder regulamentar autônomo do Presidente da República, p. 145-149.
} 
Muito embora seja de ressalvar que, pelo menos para a realidade brasileira, todos os tipos de regulamentos são normas jurídicas, é possível perceber uma afinidade especial entre os regulamentos administrativos e a espécie regulamentar autônoma criada em 2001, principalmente ao se observar o principal limite à edição do regulamento autônomo brasileiro, já explicitado, que é a ingerência em assuntos externos à Administração, especialmente quando a limitar a esfera de liberdade dos cidadãos. Remate-se com a conclusão de André Rodrigues Cyrino:

\begin{abstract}
"Pode-se dizer que, parcialmente, o regulamento previsto no novo art. 84, VI, "a" da Constituição assemelha-se ao regulamento administrativo, porquanto opera ad intra na Administração Pública, independe de lei e dispõe sobre organização e funcionamento administrativos em relações de supremacia especial. Nada obstante, deve-se deixar claro que adotamos tal classificação diante de uma Constituição concreta muito diferente da Constituição alemã do século XIX ${ }^{106,}$
\end{abstract}

\title{
4.2. Estudo de casos
}

A análise da experiência concreta travada em torno do regulamento autônomo, tanto por meio de casos em que se entendeu pela conveniência de sua edição, como em outros que, por um ou outro motivo, preferiu-se a abordagem legal stricto sensu de determinado tema, permite da maneira mais clara possível observar qual está sendo o ponto de acomodação do instituto desde a publicação da Emenda Constitucional número 32, do ano de 2001.

Já consignados alguns dos parâmetros com os quais deve trabalhar a ordem jurídica vigente para admitir a validade de determinado regulamento autonomamente elaborado, há situações já experimentadas que ajudam a compreender os limites de utilização do decreto previsto no artigo 84, inciso VI, alínea $a$ da Constituição Federal.

\footnotetext{
${ }^{106}$ CYRINO, André Rodrigues. O poder regulamentar autônomo do Presidente da República, p. 114. Os grifos são do autor.
} 
Um primeiro caso diz respeito à Lei Federal $\mathrm{n}^{\circ} 12.528$, de 18 de novembro de 2011, que criou a Comissão Nacional da Verdade no âmbito da Casa Civil da Presidência da República. Pergunta-se novamente: a criação de órgão público exige a edição de lei? Como trabalhado no subcapítulo anterior, a doutrina passou a admitir a criação de certos arcabouços administrativos por meio de regulamento autônomo, dentro do que se consideraria gestão interna administrativa, muito embora a literalidade do artigo 84, inciso VI, $a$ vede a criação de órgão por decreto.

$\mathrm{Na}$ presente questão, está justamente um caso em que não se poderia, definitivamente, prescindir da elaboração de lei para criação de um órgão público. Conquanto seja extremamente razoável que se permita a criação de certos órgãos subalternos da Administração pela via do decreto, no intuito exclusivo de melhor organizar o funcionamento do aparato administrativo, deve-se analisar, ainda que se trate de criação de órgão no interior de uma estrutura já pronta ${ }^{107}$, se o corpo a ser criado terá algum tipo de atuação externa, especialmente a limitar, de qualquer modo que seja, a liberdade de particulares.

Como é possível verificar do texto da Lei Federal n ${ }^{\circ}$ 12.528/11, para a consecução dos seus nobres objetivos, a Comissão da Verdade pode, por exemplo, "convocar, para entrevistas ou testemunho, pessoas que possam guardar qualquer relação com os fatos e circunstâncias examinados" e "determinar a realização de perícias e diligências para coleta ou recuperação de informações, documentos e dados" (artigo $4^{\circ}$ ).

Elogiável, portanto, a edição de projeto de lei para a criação do órgão, visto que elementos centrais de seu conteúdo se aproximam de matérias circunscritas à reserva legal (em que se inclui também a criação de cargos, estabelecida pelo artigo $9^{\circ}$ do diploma legal).

\footnotetext{
${ }^{107}$ O que não deixa de ser o caso em questão, ao se vislumbrar que a Comissão da Verdade se insere no âmbito da Casa Civil, este um órgão diretamente subordinado à cúpula da Administração.
} 
Outra situação aborda o caso do Decreto Federal $n^{\circ}$ 6.944, de 21 de agosto de 2009, que, entre outras medidas, dispõe sobre normas gerais relativas a concursos públicos. O referido ato normativo é explicitamente fundado na atribuição que é conferida ao Chefe do Executivo Federal pelo art. 84, inciso VI, alínea $a$, da Constituição. Ou seja, trata-se de um regulamento autônomo. O regulamento em questão foi um dos primeiros instrumentos a normatizarem a realização dos concursos públicos a nível federal, estipulando, por exemplo, o prazo de antecedência mínima para a publicação dos editais de abertura, o método de cálculo para o valor da taxa de inscrição, os casos de utilização de cadastro de reserva e regras específicas para provas práticas e orais.

O Estado do Rio de Janeiro, mais recentemente, editou o Decreto $\mathrm{n}^{\circ}$ 43.876, de 08 de outubro de 2012. De forma semelhante ao diploma federal, procura a norma estadual regulamentar questões alusivas ao conteúdo dos editais, meios de inscrição do candidato no concurso público e formas de comunicação de atos no certame.

Ambos os decretos inovam inequivocamente na ordem jurídica, estipulando direitos e obrigações dos candidatos, inclusive prevendo casos de eliminação ${ }^{108}$. Essa constatação, por si só, não seria um problema, haja vista que, como já delineado em capítulos anteriores, todo ato normativo inova de alguma forma no ordenamento jurídico. Ocorre que é questionável a opção de regulamentar algumas dessas questões por decreto (autônomo), por não se tratarem primordialmente de matéria de organização e funcionamento da Administração. Por óbvio, algumas das disposições contidas nos decretos acabam tratando simplesmente de arranjos administrativos internos. Mas, em uma visão geral, os atos normativos aqui tratados funcionam essencialmente como grandes estatutos dos concursos públicos em cada ente federativo.

\footnotetext{
${ }^{108}$ Por justiça, é preciso ressaltar que algumas das disposições, como a previsão de cotas no caso do Rio de Janeiro, apenas repetem e consolidam o teor de leis já publicadas.
} 
Assim sendo, considerando a evidente eficácia externa das normas contidas nos regulamentos, fontes importantes de direitos e deveres daqueles que se visam alcançar um cargo público pela via do concurso, mais apropriado seria a normatização dessas questões pela via da lei formal ${ }^{109}$, abrindo-se ao Administrador a possibilidade de regrar quesitos complementares por meio de regulamento de execução.

Um último evento a ser analisado remonta ao Parecer no 13/2005/MJVS, proferido no âmbito da Procuradoria Geral do Estado do Rio de Janeiro pelo saudoso Procurador do Estado e Professor Marcos Juruena Villela Souto. Tratava-se de consulta formulada pela Secretaria de Estado de Cultura do Estado do Rio de Janeiro quanto à correta aplicação de determinada lei estadual que previa punição de particular por infração contra o patrimônio cultural.

Embasando-se, inicialmente, em diploma do ano de 1981 que indicava a própria Secretaria de Estado de Cultura como competente para aplicação da sanção, verificou o órgão, quando da situação concreta, que nova lei, do ano de 2000, dispondo sobre as sanções administrativas derivadas de condutas lesivas ao meio ambiente (incluindo o meio ambiente cultural), estaria a determinar a Comissão Estadual de Controle Ambiental como órgão competente para a lavratura de auto de infração ambiental.

Diante dessa constatação, entendeu o parecerista que, a princípio, o caso seria de derrogação de lei, sendo que a norma posterior não autorizaria, portanto, a atuação da Secretaria de Estado de Cultura no caso. Indicou que uma proposta de revisão da legislação resolveria o problema do ponto de vista formal, apontando, entretanto, as mazelas esperadas de um processo legislativo.

\footnotetext{
${ }^{109}$ O PLS n $^{\mathrm{o}} 74$, de 2010, de autoria do ex-senador Marconi Perillo, pretende consolidar o tratamento do tema. As justificativas para o projeto e o seu texto atual podem ser encontrados em $\langle$ http://www.senado.gov.br/atividade/materia/getPDF.asp?t=74640\&tp=1 $\rangle$. Acesso em 21/10/2013.
} 
Assim sendo, vislumbrou, diante da edição da Emenda Constitucional número 32, uma hipótese de atuação regulamentar autônoma do Governador do Estado: seria possível, diante da nova previsão constitucional, atribuir, por decreto, a competência para processamento e aplicação de penalidades na área de patrimônio cultural à Secretaria de Estado de Cultura. Estar-se-ia, portanto, diante de matéria de organização e funcionamento.

Apesar da louvável criatividade e sagacidade do apontado parecerista, o Procurador-Geral do Estado, em interpretação restritiva e, em verdade, mais consentânea com o espírito da norma constitucional, reviu a possibilidade de edição de regulamento autônomo no caso. Entendeu-se que o Chefe do Executivo deveria "conformar-se com as matérias meramente organizativas, sem afetar as esferas jurídicas de terceiros, especialmente no que se refere ao devido processo sancionatório".

O conflito de opiniões, como o observado neste exemplo, e a complexidade que envolve uma questão aparentemente simples demonstram como o tema do regulamento autônomo surge como campo importante de estudo no novo Direito Administrativo. 


\section{CONCLUSÃO}

"o direito administrativo permanecerá...." 110 ",

Conforme apontado na apresentação do tema, intentou o presente trabalho demonstrar, precipuamente, a relação entre o novo momento do Direito Administrativo brasileiro e a necessidade de revitalização de institutos e prerrogativas clássicas da Administração, como é o caso do poder regulamentar.

Pois bem. Os novos paradigmas do direito administrativo, direcionados pela consagração de fórmulas como a consensualidade e participação administrativa, tendo como grande fim a promoção e respeito aos direitos fundamentais, vêm possibilitando a oxigenação de receitas clássicas da doutrina do direito público e dá própria prática jurídica nacional.

A elevação do princípio da juridicidade bem demonstra tal exigência. A insuficiência da lei e a sua própria derrocada diante da emergência da sociedade pós-moderna possibilitaram, junto à queda do positivismo ideológico, a consagração de uma perspectiva de ação administrativa que não se vincula total e exclusivamente à lei formal, mas a um bloco de legalidade, bem representado pelos valores e diretrizes constitucionais.

A volatilidade das relações interpessoais e o absurdo fluxo de informações exigem dos Estados modos particulares de regulação da vida social. O processo legislativo se mostra inábil para uma eficiente atuação estatal também na prestação de serviços públicos. Demanda-se, assim, maior ação do Poder Executivo e das ferramentas a si disponíveis, como forma de garantir a eficiência do Estado na persecução de valores constitucionais mais básicos.

${ }^{110}$ SUNDFELD, Carlos Ari. Direito administrativo para céticos, p. 192. 
Como decorrência disso, e sem se poder falar em desequilíbrio no conceito clássico de separação de poderes, surge um novo regulamento de execução. Uma espécie tão atualizada que renasce no seio do Direito Administrativo.

Rejeitando, pois, a cada vez mais débil caracterização do regulamento executivo como mero complemento à lei, instrumento que apenas executaria mecanicamente o comando legal, por vezes até repetindo seus preceitos, buscou-se afirmar a ampla necessidade de valorização do instituto. Necessidade que se dá por motivos que não podem ser ignorados pelo jurista, pelo administrador e pelo próprio legislador: nunca a lei poderá prever um único e possível comportamento da Administração em todas as circunstâncias particulares que possam envolver o cumprimento de uma norma. Não faz sentido, por isso, ater o regulamento de execução a uma concepção falsa da realidade.

E mais. Restando claro que as casas legislativas não figuram mais como os locais exclusivos de normatização de certos temas caros à sociedade, o regulamento é o instrumento que concretiza parâmetros impostos na lei de forma abstrata, aberta. Traduzindo: os regulamentos estão produzindo direito em escala e impacto nunca antes vistos, ainda que sempre tenham o feito pela sua própria natureza de ato normativo.

Inexoravelmente, a figura do controle, tão cara aos publicistas contemporâneos, precisa acompanhar de modo pleno essa constatação. É antiquada e perigosa a posição clássica do Supremo Tribunal Federal de não conhecer de ações diretas propostas contra regulamentos executivos, com o argumento de que se verificaria uma afronta apenas indireta à Constituição.

Por fim, viu-se que a figura do regulamento autônomo já está minimamente consolidada no direito brasileiro. A sua existência sequer merece ser discutida, tendo em vista as mudanças elencadas pela Emenda 
Constitucional número 32/2001, bem como os próprios fundamentos da alteração constitucional.

Mais útil e tarefa imprescindível é a delimitação do seu espaço no ordenamento jurídico nacional. Os limites à edição de regulamentos autônomos surgem, definitivamente, como tópico a ser profundamente estudado. A distância, por vezes encontrada, entre as caracterizações legais e constitucionais e a prática administrativa exige grande cuidado e esforço do estudioso do tema: o exame atento de casos concretos demonstra que restrições a direitos de particulares podem se transmudar no que seria mera matéria de organização e funcionamento da Administração. 


\section{REFERÊNCIAS BIBLIOGRÁFICAS}

ARAGÃO, Alexandre Santos de. A Concepção Pós-Positivista do Princípio da Legalidade. In Revista de Direito Administrativo, Rio de Janeiro, v. 236, abril/junho 2004, p. 51-64.

ARAGÃO, Alexandre Santos de. Curso de direito administrativo. Rio de Janeiro: Forense, 2012. 688p.

ARAGÃO, Alexandre Santos de. Princípio da Legalidade e Poder Regulamentar no Estado Contemporâneo, in Revista de Direito da Procuradoria Geral do Estado do Rio de Janeiro. Rio de Janeiro, v. 53, 2001, p. 37-61.

BANDEIRA DE MELLO, Celso Antônio. Curso de direito administrativo. 26a ed. São Paulo: Malheiros, 2009. 1102p.

BAPTISTA, Patrícia. Transformações do direito administrativo. Rio de Janeiro: Renovar, 2003.

BARROSO, Luis Roberto. Neoconstitucionalismo e Constitucionalização do Direito - O triunfo tardio do Direito constitucional no Brasil, in Revista eletrônica sobre a reforma do Estado, Salvador, edição número 9, Instituto brasileiro de Direito Público, 2007.

BARROSO, Luís Roberto. O controle de constitucionalidade no direito brasileiro. 5a ed. São Paulo: Saraiva, 2011. 446p. 
BINENBOJM, Gustavo. Uma Teoria do Direito Administrativo: direitos fundamentais, democracia e constitucionalização. $2^{\mathrm{a}}$ ed. Rio de Janeiro: Editora Renovar, 2008. 341p.

BIRMAN, Joel. O sujeito na contemporaneidade. Rio de Janeiro: Civilização Brasileira, 2012, 159p.

CABO MARTÍN, Carlos de. Sobre El Concepto De Ley. Madrid: Trotta, 2000. $120 \mathrm{p}$.

CAETANO, Marcello. Princípios fundamentais do direito administrativo. Coimbra: Almedina, 1996.

CANOTILHO, José Joaquim Gomes. Direito Constitucional e Teoria da Constituição. $7^{\mathrm{a}}$ ed. Coimbra: Almedina, 2003. 1522p.

CARVALHO FILHO, José dos Santos. Manual de Direito Administrativo. $16^{\mathrm{a}}$ ed. Rio de Janeiro: Lumen Juris, 2006. 1026p.

CHEVALLIER, Jacques. O Estado pós-moderno. Tradução de Marçal Justen Filho. Belo Horizonte: Fórum, 2009. 309p.

CLÈVE, Clèmerson Merlin. Atividade Legislativa do Poder Executivo. $3^{\mathrm{a}}$ ed. São Paulo: Revista dos Tribunais, 2011. 365p.

CYRINO, André Rodrigues. O poder regulamentar autônomo do Presidente da República: a espécie regulamentar criada pela EC n 32/2001. Belo Horizonte: Fórum, 2005. 215p. 
DALLARI, Dalmo de Abreu. Elementos da teoria geral do estado. $28^{\mathrm{a}}$ ed. São Paulo: Saraiva, 2009. 314p.

DELEUZE, Gilles; GUATTARI, Felix. Mil Platôs: capitalismo e esquizofrenia, vol. 2. São Paulo: Ed. 34, 2011.

DI PIETRO, Maria Sylvia Zanella. O princípio da supremacia do interesse público: sobrevivência diante dos ideais do neoliberalismo. In: Maria Sylvia Zanella Di Pietro; Carlos Vinícius Alves Ribeiro. (Org.). Supremacia do interesse público e outros temas relevantes do direito administrativo. São Paulo: Atlas, 2010, p. 85-102.

ENTERRÍA, Eduardo García de. Democracia, jueces y control de la Administración. $3^{\text {a }}$ edição. Madri: Civitas, 1997. 340p.

ENTERRÍA, Eduardo García de; FERNÁNDEZ, Tomás-Ramón. Curso de direito administrativo. Tradução de Arnaldo Setti. São Paulo: Editora Revista dos Tribunais, 1990. 957p.

FAGUNDES, Miguel Seabra. O Controle dos Atos Administrativos pelo Poder Judiciário. $8^{\mathrm{a}}$ ed., atualizada por Gustavo Binenbojm. Rio de Janeiro: Forense, 2010.

GORDILlO, Agustín. Tratado de Derecho Administrativo. $8^{\mathrm{a}}$ ed. Buenos Aires: Fundación de Derecho Administrativo, 2003.

GRAU, Eros Roberto. O Direito Posto e o Direito Pressuposto. $7^{\mathrm{a}}$ ed. São Paulo: Malheiros, 2008. 367p. 
GUERRA, Sérgio. Regulação e maleabilidade normativa à luz do direito administrativo econômico. In: FREITAS, Daniela Bandeira de; VALLE, Vanice Regina Lírio do (Coord.). Direito administrativo e democracia econômica. Belo Horizonte: Fórum, 2012, p. 223-244.

HART, Herbert L. A. O Conceito de Direito. Tradução de Armindo Ribeiro Mendes. $6^{a}$ ed. Lisboa: Fundação Calouste Gulbenkian, 2011. 345p.

KELSEN, Hans. Teoria Pura do Direito. Tradução de João Baptista Machado. $6^{a}$ ed. São Paulo: Martins Fontes, 1998.

KRELL, Andreas J. Leis de normas gerais, regulamentação do Poder Executivo e cooperação intergovernamental em tempos de Reforma Federativa. Belo Horizonte: Fórum, 2008. 154p.

KUHN, Thomas S. A estrutura das revoluções científicas. Tradução de Beatriz Vianna Boeira e Nelson Boeira. $3^{\text {a }}$ ed. São Paulo: Editora Perspectiva, 1991. $257 \mathrm{p}$.

LARENZ, Karl. Metodologia da Ciência do Direito. Tradução de José Lamego. $3^{a}$ edição. Lisboa: Fundação Calouste Gulbenkian, 1997.

MARQUES NETO, Floriano de Azevedo. Poderes da Administração Pública. In: FIGUEIREDO, Marcelo (Coord.). Novos rumos para o direito público: reflexões em homenagem à Professora Lúcia Valle Figueiredo. Belo Horizonte: Fórum, 2012, p. 221-235. 
MARTINS, Augusto Henrique Werneck. Reflexões acerca do poder regulamentar - Propostas à Constituinte, in Revista de Direito da Procuradoria Geral do Estado do Rio de Janeiro. Rio de Janeiro, v. 40, 1988, p. 45-49.

MELLO, Vanessa Vieira de. Regime Jurídico da Competência Regulamentar. São Paulo: Dialética, 2001. 142p.

MENDES, Gilmar Ferreira. Jurisdição Constitucional: o Controle Abstrato de Normas no Brasil e na Alemanha. $5^{\mathrm{a}}$ edição. São Paulo: Saraiva, 2005.

MOREIRA NETO, Diogo de Figueiredo. Quatro paradigmas do direito administrativo pós-moderno: legitimidade: finalidade: eficiência: resultados. Belo Horizonte: Fórum, 2008. 161p.

MORGADO, Cíntia. A nova face da separação de poderes - Capacidades institucionais, vinculação dos poderes e constitucionalismo cooperativo, in Revista de Direito da Procuradoria Geral do Estado do Rio de Janeiro. Rio de Janeiro, v. 66, 2011, p. 64-93.

NUNES, Simone Lahorgue. Os Fundamentos e os Limites do Poder Regulamentar no Âmbito do Mercado Financeiro. Rio de Janeiro: Renovar, 2000. 200p.

OTERO, Paulo. Legalidade e Administração Pública - O sentido da vinculação administrativa à juridicidade. Coimbra: Almedina, 2003. 1192p.

PIÇARRA, Nuno. A separação dos poderes como doutrina e princípio constitucional: um contributo para o estudo das suas origens e evolução. Coimbra: Coimbra Editora, 1989. 
RIVERO, Jean. Curso de Direito Administrativo Comparado. Tradução de J. Cretella Jr. $2^{a}$ ed. São Paulo: Editora Revista dos Tribunais, 2004. 239p.

RIVERO, Jean. Direito administrativo. Tradução de Rogério Ehrhardt Soares. Coimbra: Almedina, 1981.

SARMENTO, Daniel (coord.). Interesses públicos vs. Interesses privados: desconstruindo o princípio da supremacia do interesse público. Rio de Janeiro: Lumen Juris, 2005.

SCHAUER, F. Playing by the Rules: A Philosophical Examination of RuleBased Decision-Making in Law and in Life. Oxford: Oxford University Press, 1991.

SCHIER, Paulo Ricardo. Filtragem Constitucional: construindo uma nova dogmática jurídica. Porto Alegre: Sérgio Antonio Fabris Editor, 1999.

SILVA, José Afonso da. Curso de Direito Constitucional Positivo. $33^{\mathrm{a}}$ ed. São Paulo: Malheiros, 2010. 926p.

SOUTO, Marcos Juruena Villela. Direito Administrativo Regulatório. $2^{\mathrm{a}}$ ed., Rio de Janeiro: Lumen Juris, 2005.

SOUTO, Marcos Juruena Villela. Procuradoria Geral do Estado do Rio de Janeiro. Parecer nº 13/2005 - MJVS, de 03 de maio de 2005. 
SOUZA NETO, Cláudio Pereira de; SARMENTO, Daniel (coord.). A Constitucionalização do Direito: fundamentos teóricos e aplicações específicas. Rio de Janeiro: Lumen Juris, 2007.

STF, ADI n ${ }^{\circ}$ 748/RS. Relator: Min CELSO DE MELLO. Brasília. Data de julgamento: 01/07/1992.

STF, ADI n ${ }^{\circ}$ 561-8/DF, Relator: Min. CELSO DE MELLO. Brasília. Data de julgamento: 23/08/1995.

STF, ADI no 3232/TO, Relator: Min. CEZAR PELUSO. Brasília. Data de julgamento: 14/08/2008.

STF, ADI no 3664/RJ, Relator: Min. CEZAR PELUSO. Brasília. Data de Julgamento: 01/06/2011.

STF, ADI no 2583/RS. Relatora: Min. CARMEN LÚCIA. Brasília. Data de julgamento: 01/08/2011.

STF, ADI-AgR no 4218/DF. Relator: Min. LUIZ FUX. Brasília. Data de julgamento: $13 / 12 / 2012$

STRUCHINER, Noel. Direito e Linguagem: uma análise da textura aberta da linguagem e sua aplicação ao direito. Rio de Janeiro: Renovar, 2002.

SUNDFELD, Carlos Ari. Direito administrativo para céticos. São Paulo: Malheiros, 2012. 192p. 
SUNDFELD, Carlos Ari. O Direito Administrativo entre os clips e os negócios, in Revista de Direito Público da Economia. Belo Horizonte, ano 5, n. 18, abr. 2007.

TÁCITO, Caio. Parecer sobre o poder regulamentar do Conselho Monetário Nacional e da Comissão de Valores Mobiliários, in Revista da CVM. Rio de Janeiro, v. 4, n. 12, 1986, p. 27-34.

WEHLING, Arno. Montesquieu, Barão de. In: BARRETO, Vicente de Paulo. (Org.). Dicionário de Filosofia do Direito. Rio de Janeiro: Unisinos/Renovar, 2006, p. 585-587. 